\title{
Strategic Idealizations of Science to Oppose Environmental Regulation: A Case Study of Five TMDL Controversies
}

\author{
David S. Caudill* \& Donald E. Curley**
}

\section{INTRODUCTION}

Manufacturing uncertainty and promoting inappropriate criteria for assessing the quality of evidence . . are central elements of a strategy for opposing regulation, impeding discussion of values and societal priorities, and closing out input from those whose health and quality of life are impacted by regulatory decisions.

The accusation has become commonplace - regulated parties derail, delay, and weaken governmental efforts to protect public health and the environment by employing a series of questionable strategies to attack the scientific evidence behind such efforts. Proponents of environmental regulation have catalogued those strategies as including

* J.D., Ph.D., Professor and Arthur M. Goldberg Family Chair in Law, Villanova University School of Law. This Article is based upon research funded by the Project on Scientific Knowledge and Public Policy (SKAPP), based at the George Washington University School of Public Health and Health Services, through an unrestricted grant from the Common Benefit Litigation Expense Trust, a fund established pursuant to court order in the Silicon Gel Breast Implant Products Liability Litigation. Professor Caudill was the lead investigator, and co-author Dr. Curley was the primary scientific investigator on the project. The authors acknowledge the assistance of Professor Richard Redding at Chapman University School of Law and Emeritus Professor John Hyson at Villanova University School of Law, who were also investigators on this SKAPP project, and the research assistance of Chris Metzger, J.D. candidate 2009, and Francine Li, J.D. candidate 2010, both at Villanova University School of Law. The authors are also grateful to the many attorneys, regulatory personnel, and environmental engineers who were involved in the subject TMDLs and willing to talk about their involvement in the process. Finally, the authors appreciate the critical comments on an earlier draft of this Article by Martha E. Blasberg and Professors Robert Humston, Robin K. Craig, J.B. Ruhl, Holly Doremus, and David L. Markell; any errors in the Article, nevertheless, remain the responsibility of the authors.

** M.S.E., A.M., Ph.D.; Dr. Curley is a Professional Engineer (P.E.), a certified planner (A.I.C.P.), and the principal of Donald Curley, P.C., a consulting engineering and planning corporation. He has taught Civil and Environmental Engineering courses as an adjunct professor at the University of Pennsylvania, Villanova University, and Drexel University, as well as City Planning courses as a lecturer at the University of Pennsylvania.

1. Polly J. Hoppin \& Richard Clapp, Science and Regulation: Current Impasse and Future Solutions, 95 Am. J. PUB. HeAlTH S8, S8 (Supp. 1, 2005). 
manufacturing or magnifying uncertainty; ${ }^{2}$ (2) demanding "sound science" (and thereby imposing unreasonable standards of evidence) ${ }^{3}$ and (3) data quality initiatives that permit deconstruction of credible studies by highlighting inevitable assumptions, funding sources, and areas for further research. ${ }^{4}$ Such strategies can be termed "idealizations" of science insofar as they rely on an unrealistic image of good science as somehow capable of avoiding tentative conclusions, institutional interests, consensual assumptions, and the need for further research.

One might reasonably ask how such strategies could ever work, given our familiarity with (1) regulatory science's frequent probabilistic reasoning, uncertainties, genuine disputes, imperfect assessments, insufficient resources, and incomplete data, as well as (2) scientists' respective theoretical commitments, experimental conventions, research expectations, rhetorical advocacy, and affiliational interests. ${ }^{5}$ There is, however, an obvious cultural authority enjoyed by science and scientists, and our reliance on scientific progress and utility leads naturally to some level of idealization. ${ }^{6}$ More to the point, there is also evidence that strategies based upon an idealization of science do "work" in legal contexts. ${ }^{7}$ Trial judges who romanticize science's capacity to resolve legal disputes may sometimes reject credible evidence because an expert concedes the pragmatic limitations and uncertainties of her conclusion; at other times, they admit flawed evidence solely on the basis of the expert's confidence and credentials. ${ }^{8}$ In the regulatory context, the

2. See generally DAVID MichaELs, DoubT is THEIR Product: How Industry's AsSAUlt on Science Threatens Your Health (2008). See also David Michaels \& Celeste Monforten, Manufacturing Uncertainty: Contested Science and the Protection of the Public's Health and Environment, 95 AM. J. PUB. HEALTh S39 (Supp. 1, 2005) (noting that those against public health and environmental regulation sometimes manufacture uncertainty by doubting the scientific evidence on which the regulatory entities rely).

3. See generally Roni A. Neff \& Lynn R. Goldman, Regulatory Parallels to Daubert: Stakeholder Influence, "Sound Science," and the Delayed Adoption of Health-Protective Standards, 95 AM. J. Pub. Health S81 (Supp. 1, 2005) (discussing how pressures for excessive review, documentation, and "sound science" are used to impose unreasonable standards of evidence in health regulation).

4. See generally Wendy Wagner, The Perils of Relying on Interested Parties to Evaluate Scientific Quality, 95 AM. J. PuB. Health S99 (Supp. 1, 2005) (discussing how sound science can appear controversial when individual methodological decisions are challenged).

5. See David S. Caudill \& Lewis H. LaRue, No Magic Wand: The Idealization of SCIENCE IN LAW 104-19 (2006) (discussing generally the social, institutional, and rhetorical aspects of scientific practice as distinguished from the core elements of science including hypothesis, data collection, testing, publication and peer review, and application (or, in the alternative, refutation and revision)).

6. See id. at 36-41.

7. See id. at 2,31-44. Also see the examples offered in Michaels \& Monforten, supra note 2; Neff \& Goldman, supra note 3; Wagner, supra note 4.

8. See CAUDILl \& LARUE, supra note 5, at 15-28, 31-36. 
Environmental Protection Agency's (EPA's) recent failure to regulate carbon dioxide emissions was arguably due to the EPA Administrator's invocation of the scientific uncertainties concerning the causal link between greenhouse gas emission and global warming. ${ }^{9}$ The question remains, however, when does an argument based on scientific uncertainty reflect a valid concern, and when is such an argument merely strategic?

This Article is based on a study that was structured to identify whether and how arguments and challenges based on idealizations of science are used in the initial (pre-litigation) stages of local water quality controversies. Based upon the geographic location, research interests, and previous professional experiences of the authors, we decided to focus on the scientific disputes that followed from five Total Maximum Daily Loads (TMDLs) ${ }^{10}$ recently issued to pollutant dischargers with

9. See Massachusetts v. EPA, 415 F.3d 50, 58 (D.C. Cir. 2005) (Petitioners claimed that the "refusal to regulate rested entirely on scientific uncertainty"; the court disagreed, referring to "many 'policy' considerations that ... warranted ... forbearance," including risk assessment), rev'd, $127 \mathrm{~S}$. Ct. 1438 (2007). In reversing, the United States Supreme Court held that the EPA cannot "avoid its statutory obligation by noting the uncertainty surrounding various features of climate change and concluding that it would therefore be better not to regulate at this time." $127 \mathrm{~S}$. Ct. at 1444 . Of course, the role of politics and the Bush administration's environmental agenda, which reflects a cautious approach to regulation (e.g., more study), should not be overlooked. The asserted uncertainties likely do not alone explain the EPA's decision to forego regulation.

10. The term "load" in TMDL refers to the amount of an identified pollutant discharged into an impaired body of water; the "maximum" is the amount beyond which a previously designated water quality standard cannot be attained, and that amount is allocated to the sources of the pollutant. See Clean Water Act, 40 C.F.R. § 130.2(e)-(f) (2007). The Clean Water Act distinguishes between point and nonpoint sources of pollution, such that a TMDL for a particular pollutant is the sum of the wasteload allocation (WLA) from point sources, the load allocation (LA) from nonpoint sources, natural background levels, an allocation for future growth, and a margin of safety. See id. $\S$ 130.2(g)-(i). "Point source" refers to pipes, ditches, channels, wells, discrete fissures, containers, rolling stock, concentrated animal feeding operations, and even floating vessels from which pollutants are discharged. See Clean Water Act, 33 U.S.C. § 1362 (14) (2000). By contrast, a "nonpoint source" is a source of pollution without a single point of origin, and generally refers to diffuse runoff, typically caused by rainfall or snow melting; pollutants may result, for example, from agricultural activities, or from commercial and residential development, including roads and parking lots. See Edward B. Witte \& David P. Ross, Nonpoint Source Pollution Control, in The CleaN WATER ACT HANDBOOK 193 (Mark A. Ryan ed., 2d ed. 2003). "The definition of nonpoint source pollution in the Clean Water Act . . . does not exist .... [A]nything that is not a point source and yet conveys pollutants to our nation's waters is a nonpoint source." Id. at 192-93. However, the classification of stormwater runoff as a point source, and regulation of industry and municipal stormwater systems under NPDES permits, see Olga L. MOYA \& ANDREW L. FONO, FEDERAL ENVIRONMENTAL LAW: THE USER'S GUIDE 297-300 (2d ed. 2001) (providing an overview of point sources), introduces some confusion. For example, the Wissahickon TMDL analyzed in this study was both a point source and a nonpoint source TMDL, but sediment loads from stormwater were considered point sources. See WISSAHICKON CREEK TMDL, infra note 110; see also Commonwealth of Pennsylvania Total Daily Maximum Loads, http://www.dep.state.pa.us /watermanagement_apps/tmdl/default.aspx (last visited Sept. 23, 2008) (providing information on Pennsylvania TMDLs).

While TMDLs for point source discharges are relatively straightforward, "the current regulatory 
respect to impaired waters in the Philadelphia area. From March 1, 2007, to November 30, 2007, we collected and examined documents related to the five TMDLs, including, as to each TMDL, its respective modeling reports, public comments and agency responses, technical supporting documents, and initial legal challenges (including appeals, motions, and briefs). To supplement our understanding of the disputes, we also interviewed various EPA and Pennsylvania Department of Environmental Protection (PaDEP) officials, private attorneys representing local stakeholders, scientists, representatives of advocacy groups, and university professors with expert knowledge of the TMDL program. The purpose of this Article is to describe the results of our study, including our sense that idealized arguments, at least in the early stages of TMDL disputes, are not very effective.

Briefly, the TMDL program is a cooperative effort between federal and state environmental agencies with origins in the Clean Water Act, which regulates water pollution to protect U.S. water resources (e.g., lakes and streams), maintain aquatic life, and preserve recreational uses. $^{11}$ The National Pollutant Discharge Elimination System (NPDES) in the Act provides for discharge permits, ${ }^{12}$ as well as procedures for states to establish TMDLs for pollutants in their impaired waters, including listing of polluted waters, ranking of priorities, identifying pollution loads for safety, and taking steps to reduce point and nonpoint loadings to that level. ${ }^{13}$ As to discharge permits, the 1972 amendments

framework does not adequately provide for the control of nonpoint source pollution .... There are limited technical controls that can be applied to the sources, even if the sources can be easily identified." Witte \& Ross, supra, at 192. In another formulation, "whereas point sources are subject to well-defined standards of control technology and strict numerical limits, nonpoint source regulation is a picked-over smorgasbord of studying, planning, and promises of federal money to pay for the studying and planning." Josh Clemons, Addressing Nonpoint Source Pollution in the Fifth and Eleventh Circuits: Could Pronsolino Happen in Mississippi and Alabama?, 21 J. LAND USE \& ENVTL. L. 55, 56 (2005).

11. 33 U.S.C. $\S \S 1251-1387$. The 1948 Water Pollution Control Act was focused on state efforts, and the 1965 revisions required states to develop water quality standards by 1967 . The 1972 Clean Water Act was the result of major amendments to the Water Pollution Control Act, including enforceability by the EPA (created in 1970). See JOEL M. GROSS \& LYNN DODGE, CLEAN WATER ACT 5-8 (2005). For a recent history of the Clean Water Act, see PAUL ChARLES MilazZO, UNLIKELY ENVIRONMENTALISTS: CONGRESS AND ClEAN WATER, 1945-1972 (2006). The use of science in the TMDL program begins with the setting of water quality standards since the "TMDL process is primarily a measurement process" to achieve a specific criterion for a specific, designated

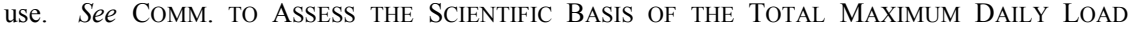
Approach to Water Pollution, Nat'L Research Council, Assessing the TMDL Approach TO WATER QUALITY MANAGEMENT 7-8 (2001). Listing impaired waters is also science intensive, but in this study we focus on the use of science in the development of TMDLs and in the initial or early scientific challenges thereto by stakeholders. See infra notes 15-16 and accompanying text.

12. Clean Water Act $\S 402,33$ U.S.C. $\S 1342(a)-(b)$.

13. Clean Water Act $\S 303(d), 33$ U.S.C. $\S 1313(d)$. 
to the Clean Water Act envisioned uniform, national technology-based (i.e., not based on water quality) standards to limit effluent discharges by industries. $^{14}$ As to TMDLs, the 1972 amendments also envisioned a water-quality-based program in which the states each (1) adopt water quality standards necessary for various uses (e.g., public water supply, recreational, etc.) that define what counts as impaired in the identification, listing, and prioritization of impaired waters, and (2) establish the TMDL for identified pollutants 15 "necessary to implement the applicable water quality standards with seasonal variations and a margin of safety...." However, "state and federal officials have begun to implement [the TMDL process] in earnest only recently, and much of that effort was a response to forty lawsuits that had been filed against the EPA. [In 2005, TMDLs had] been set for only a small fraction of impaired waters." 17 Significantly, even when pollutant dischargers are in full compliance with their permits, states must identify and prioritize impaired waters, prepare TMDLs for each pollutant, and submit the lists and TMDLs to the EPA for approval (or disapproval, in which case the EPA must prepare its own list and TMDLs) ${ }^{18}$ Finally, states must provide for public review of their TMDLs and incorporate their TMDLs into their water quality management program. ${ }^{19}$

Because our study focused on conventional TMDLs recently promulgated in eastern Pennsylvania, ${ }^{20}$ the ongoing controversies

14. See GROSS \& DODGE, supra note 11 , at 8-9, 25-46.

15. See id. at $47-48$.

16. Clean Water Act $\S 303(d)(1)(C), 33$ U.S.C. $\S 1313(d)(1)(C)$.

17. GRoss \& DoDGE, supra note 11, at 54. For 29,711 waters identified to the EPA as impaired, there were 11,408 TMDLs promulgated as of May 2005. Id. "The extent of TMDL promulgation varies widely by state." Id. (There were 1780 reported impairments in Minnesota as of May 2005, but only twenty-five TMDLs; in contrast, Kansas had 2308 TMDLs for 2623 impairments). For an update and critical assessment of state TMDL efforts, see generally Kelly Seaburg, Murky Waters: Courts Should Hold that the "Any-Progress-Is-Sufficient-Progress" Approach to TMDL Development Under Section 303(d) of the Clean Water Act Is Arbitrary and Capricious, 82 WASH L. REV. 767, 772-776 (2007) (explaining the mandatory requirements the Clean Water Act has imposed on the EPA and states for TMDL development).

Regarding the "forty lawsuits," see Linda A. Malone, The Myths and Truths That Threaten the TMDL Program, 32 ENVTL. L. REP. 11,133, 11,133 (2002) (describing the 1978 court order forcing the EPA to identify TMDL pollutants, various citizen suits forcing the EPA to require states to submit TMDLs, and the litigation forcing the EPA to deal with minimal state TMDL submissions either by working with the state to encourage compliance or by making its own TMDL list).

18. Laurie K. Beale \& Karin Sheldon, TMDLs: Section 303(d), in THE Clean Water Act HANDBOOK, supra note 10, at 205, 207 (citing 33 U.S.C. $§ 1313(d) ; 40$ C.F.R. 1 §§ 130.2(j), 130.7(b)(4), 130.7(c)(1), 130.7(d)(1)-(2)). (d)(2)).

19. Id. at 207-08 (citing 33 U.S.C. $§ 1313(\mathrm{e})(3)(\mathrm{C}) ; 40$ C.F.R. $\S \S 130.5-6,130.7(\mathrm{C})(1)(\mathrm{ii}) \&$

20. In a state-of-readiness survey by the U.S. General Accounting Office (GAO) regarding TMDLs, "[forty] states reported confidence in their ability to identify point sources of pollution (not 
surrounding the TMDL program-including TMDLs for agriculture ${ }^{21}$ and pollutant trading schemes ${ }^{22}$ - are beyond the scope of this Article. However, it bears mentioning that the issues of the "soundness" of TMDL science, the challenge of scientific uncertainties, and the effect of political and economic interests on science have been part of the national TMDL controversy. In July 1999, during the last years of the Clinton administration, the EPA issued its draft of a comprehensive TMDL regulation $^{23}$ to improve pollution control by focusing on nonpoint sources. The opposition was overwhelming - a perfect storm of antigovernment and anti-Clinton sentiments, state concerns about resources and funding, industry complaints, House and Senate hearings receptive to critics, and even (as the proposal was watered down with concessions) criticism by environmental groups. ${ }^{24}$ Upon issuance of the final TMDL rules in July $2000,{ }^{25}$ the EPA was "left without a single, unified constituency" as well as "a rule nobody liked." 26 Congress delayed application of the rule by way of an appropriations rider until October $2001,{ }^{27}$ and the controversy continued until the rule's effective date was delayed until March 2003; ${ }^{28}$ eventually it was withdrawn. ${ }^{29}$

that hard a trick, given that point source loadings are characterized in each NPDES permit) . . while [twenty-nine] states felt they had sufficient data to develop point source TMDLs." Oliver A. Houck, The Clean Water Act TMDL Program V: Aftershock and Prelude, 32 EnVTL. L. REP. 10,385, 10,390 (2002) (citing U.S. Gen. Accounting OfFice, Water Quality: Key EPA AND STATE Decisions LIMITED BY INCONSISTENT AND INCOMPLETE DATA 43-44 fig.7 (2000)).

21. See Clemons, supra note 10, at 56; see also William L. Andreen, Water Quality TodayHas the Clean Water Act Been a Success?, 55 AlA. L. Rev. 543, 564 (2004).

22. See Ann Powers, The Current Controversy Regarding TMDLs: Pollutant Trading, 4 VT. J. ENVTL. L. 9 (2003).

23. Proposed Revisions to the Water Quality Planning and Management Regulations, 64 Fed. Reg. 46,012 (Aug. 23, 1999) (to be codified at 40 C.F.R. pt. 130). In 1998, President Clinton "announced his administration's Clean Water Action Plan to protect and restore the nation's waters." FranK P. GRAD, TREATISE ON ENVIRONMENTAL LAW § 3.03[2][a-2], 3-107 (Matthew Bender \& Co., Inc. 2002) (citing 63 Fed. Reg. 14,109 (Mar. 24, 1998) (entitled "Notice of Availability of Clean Water Action Plan")). "Without undercutting the established emphasis of the 1972 Clean Water Act on effluent limitations of point sources, the new plan expand[ed] the interpretation of statutory authorizations by focusing on nonpoint sources, such as runoff from urban and agricultural lands and facilities...." Id. at 3-108.

24. See Houck, supra note 20, at 10,386-88.

25. Revisions to the Water Quality Planning and Management Regulation..., 65 Fed. Reg. 43,586 (July 13, 2000) (to be codified at 40 C.F.R. pts. 9, 122, 123, 124, 130). Nonpoint sources are explicitly included in TMDL framework. Id. at 43,588. TMDLs must be scheduled for promulgation within ten years. Id. at 43,591. Further, states must provide an implementation plan and assurance that TMDL goals will be met. Id.

26. Houck, supra note 20, at 10,388.

27. H.R. 4425, 106th Cong. (2000) (prohibiting the EPA from spending money to implement the rule, and mandating a study by the National Academy of Science on the adequacy of TMDL science).

28. Delay of Effective Date of Revisions, 66 Fed. Reg. 41,817-22 (Aug. 9, 2001) (to be codified at 40 C.F.R. pts. 9, 122, 123, 124, 130). 
Identification of pollutants and reduction through controlling discharges at their source might seem relatively straightforward from a scientific perspective, but scientific controversies abound in the TMDL context. Identifying sources (including point source and nonpoint sources) is difficult, as is measuring pollutants, understanding how much of a pollutant can be "handled" by difficult-to-understand aquatic ecosystems, and determining downstream and upstream effects. Moreover, the scientific issues of identifying an impaired water at the preliminary stage, including arguments about whether a water is impaired, are different from the issues at the TMDL stage when the state (or the EPA) is in a remedial mode. This latter stage includes arguments about whether the TMDL will be effective in alleviating an acknowledged problem. Our focus in this study is on the TMDL stage (although stakeholder comments criticizing a TMDL often criticize the original impairment listing as questionable), where the scientific burden of proof may be effectively lower than it is at the earlier "listing" stage. In the earlier stage, states are not obligated to make an impairment finding if the evidence is inconclusive on whether a particular lake or stream fails to meet the state's water quality standards. Science-based challenges to impairment findings, therefore, may not need to be strong or precise to prevent listing. By contrast, after an impairment finding, establishing TMDLs for relevant pollutants (a single body of water may be subject to multiple TMDLs) is mandatory, and that legal obligation may affect administrative and judicial demands concerning the quality of the science supporting a TMDL. If TMDLs must be established with available or easily obtained science, then science-based arguments may need to be particularly strong and precise by offering more data, studies, alternative methodologies and models, or uncertainty analyses, rather than simply demanding them. The reasonableness or legitimacy of science-based demands for more study and data, and for less uncertainty,

\footnotetext{
Regarding the final TMDL rules:

The July 2000 rule was extremely controversial. The agency had received more than 34,000 comments on the proposed TMDL rule....

More than a dozen groups, including farm groups, environmental groups, municipal wastewater treatment officials, and state water pollution agencies, filed challenges to the revised TMDL rule. ... The current rule remains in effect ....

Christopher L. Bell et al., Environmental Law Handbook 323 (Thomas F.P. Sullivan ed., 19th ed. 2007).

29. Withdrawal of Revisions to the Water Quality Planning and Management Regulation, 68 Fed. Reg. 13,608 (Mar. 19, 2003) (to be codified at 40 C.F.R. pts. 9, 122, 123, 124, 130). For detailed accounts of the controversy over the July 2000 rule, see generally Houck, supra note 20; Malone, supra note 17.
} 
depends upon the context of regulation; we selected a context (TMDL disputes) characterized by legal compulsion and urgency. ${ }^{30}$

Criticism of existing "TMDL science" was a centerpiece throughout the controversy over revising and strengthening the TMDL program:

There [was] a broad consensus of support among stakeholders for the use of ... "good science." However, there [was] a significant difference of opinion, particularly between environmental activists and the regulated community, over exactly what constitutes good science. There [was] also concern by the regulated community that the development and implementation of [new] regulations may precede the development of appropriate scientific methods.

At a hearing in March 2000, on the proposed TMDL revisions, an environmentalist attorney testified, "[w]e cannot afford to wait for perfect data and a perfect understanding of the interaction between pollutants and the aquatic ecosystem before taking steps to correct

30. The compulsive nature of TMDL implementation makes "adaptive implementation" (AI) an attractive alternative to most current TMDL programs:

The central theory of AI is that uncertainty can be reduced over time only by studying and/or modeling watershed and water quality responses to load reductions, implementing controls, and then carefully and methodically assessing the results in order to learn while doing. The learning would be incorporated into improved modeling and/or analysis that would, in turn, lead to more informed decision making.

LeOnard Shabman et al., Nicholas Inst. for the EnVtl. Policy SOlutions at Duke UniV., ADAPTIVE IMPLEMENTATION OF WATER QUALITY IMPROVEMENT PLANS: OPPORTUNITIES AND CHALlENGES 10 (2007), available at http://nicholas.duke.edu/institute/adaptive-water.pdf. Indeed, AI has been proposed to overcome the types of controversies that are the subject of this study:

A TMDL implementation plan that ignores uncertainty and the cost of error can often generate stakeholder disagreements and difficulty in moving forward with a TMDL plan. Some, citing uncertainty and possible costs of "overspending" on controls, argue for more study. Others, seeing the same uncertainty and concerned about being "protective of water quality," argue for even more stringent [margins of safety] (with [their] attendant costs). Meanwhile, disputes could arise over the scope of regulatory authorities ... and the adequacy of the financial resources to implement the plan. The result is often stalemate, legal action, and delay in implementing any water quality improvements. Adaptive decision-making approaches are well-suited to breaking the deadlock and promoting consensus among disputing parties.

Id. at 38-39. While the potential for AI (and existing applications in some states) is beyond the scope of this study, our findings are consistent with the above assessment and therefore make the foregoing argument more compelling.

31. Donald Galya et al., EPA's New Water Quality Initiative: Issues for Stakeholders, 13 NAT. RESOURCES \& ENV'T. 562, 564 (1999). Due to states' lack of both funding for a "state-of-thescience approach" and a "large resource base with scientific and regulatory skills," their agencies "may tend to use less resource intensive, and less scientifically appropriate, approaches." Id. at 565. 
serious water pollution problems." 32 Later that year, Congressman Allen Boyd (Second District of Florida) released "TMDL 101" for the press:

The truth is that TMDL rules are fundamentally flawed. Independent scientific reviews of the rules have confirmed criticism by the National Academy of Science's National Research Council that EPA's science does not support its decision-making. ... I am a cosponsor of [a bill that would] require that the science be peer-reviewed. ... [L] et's make sure that our data [are] accurate and our science is sound before imposing rules that could have drastic implications on the many Americans whose livelihood are at stake. ${ }^{33}$

The National Research Council report (to which Boyd refers) is somewhat ambivalent; on the one hand, it seems suspicious of

[t]he call for "sound science" in the TMDL program. ... By definition, science is [a] process of continuing inquiry. Thus, calls to make policy decisions based on "the science," or calls to wait until "the science is complete," reflect a misunderstanding of science. Decisions ... must be made, based on a preponderance of evidence ... 34

On the other hand, the report identified large gaps in TMDL data (especially with regard to nonpoint sources), recommended increased monitoring to produce accurate sampling and reduce uncertainty, and stated that many state water quality standards are flawed. ${ }^{35}$ Thus TMDL science is neither worthless nor perfect, but somewhere in between, and the debate over its sufficiency for making regulatory decisions will continue. While we do not purport in this Article to bring closure to that

32. Proposed Revisions to EPA Water Quality Regulations (TMDLs): Hearing Before the Subcomm. on Fisheries, Wildlife and Water Comm. on Envtl. and Pub. Works, 106th Cong. 2 (2000) (statement of Richard A. Parrish, Southern Environmental Law Center).

33. Press Release, Congressman Allen Boyd (2d Dist. Fla.), TMDL 101 (Oct. 13, 2000), available at $\mathrm{http}: / / \mathrm{www}$.house.gov/boyd/br101300.html. The stakes involve not only expensive control equipment upgrades, but also the threat of shutting down industrial facilities.

34. NAT'L RESEARCH COUNCIL, supra note 11, at 89. In Houck's view, "On one level, the NAS report is an affirmation of the TMDL program. The message on the adequacy of the supporting science was blunt: the science is there, its uncertainty can be reduced, and uncertainties that remain should not be used as an excuse for delay or inaction." Houck, supra note 20, at 10,391.

35. See NAT'L RESEARCH COUNCIL, supra note 11, at 5, 32-38, 81-82, 90 (discussed in Houck, supra note 20, at 10,391). Interestingly, Houck considers the National Research Council's TMDL assessment to be "a rush job" by a "small group with an attitude." Houck, supra note 20, at 10,392. For example, the National Research Council report states the authors' preference for state over federal responsibility is not an assessment of scientific adequacy, but is "taking sides in a political debate over federalism." Id. "Under normal circumstances, NAS reports are written over several years, by scientists with little financial or political connection to the issues before them, and with a balance of points of view." Id.; see also id. at 10,393 (suggesting the TMDL panel chair was an industry witness with an agenda, and that the report's principal author was already critical of the TMDL program). 
debate, we do hope to illuminate the issue of uncertainty in regulation by bracketing off the abstract and generalized political discourse and focusing in on the early stages of a few actual controversies within the TMDL program.

The enormous complexity of the TMDL program, ${ }^{36}$ pitting strict statutory demands against limited state resources as well as potentially high costs of industry compliance, ends up highlighting the pragmatic limitations and uncertainties of science in law:

The Achilles' heel of water quality standards-based regulation has always been the difficulty of ascribing and quantifying environmental effects for particular discharge sources. There is always another possible source, or another possible reason that ... fish ... are dying. There is always an arguable threshold level for pollutants that may not harm fish .... And when we come to more complex biological impacts such as the fate and effects of nutrients ... downstream, we are beyond any pretense of precise mathematics for cause and effect decisions.... "Good Science". . ${ }_{37}$ does not mean precision; it means the best science can do at the time. ${ }^{37}$

Many scientific challenges to TMDLs are surely valid; it is reasonable to demand that underlying calculations "be rationally derived from the best available data," but to require more - "the hypertechnical, isolated, cause-and-effect kinds of proof"-is unrealistic. "If proof of that kind is required, TMDLs will never get off the ground. Science, in this area of the law, will never deliver precision." 38 But where is the line between a

36. As of May 2005, almost 30,000 impaired waters were identified to the EPA by states, many with multiple pollutants. See Gross \& DoDge, supra note 11, at 54; see also Memorandum from Benjamin H. Grumbles, Asst. Adm'r, EPA, to EPA Directors, Establishing TMDL "Daily" Loads in Light of the Decision by the U.S. Court of Appeals for the D.C. Circuit in Friends of the Earth, Inc. v. EPA, et al., No. 05-5015, (Apr. 25, 2006) and Implications, for NPDES Permits (Nov. 15, 2006) ("[M]ore than 20,000 TMDLs have been established.... EPA's database also shows that approximately 65,000 causes of impairment still need to be addressed by TMDLs.").

37. Oliver A. Houck, The Clean Water act TMdL Program: Law, Policy, and IMPLEMENTATION 58-59 (2d ed. 2002). Significantly, the Clean Water Act, 33 U.S.C. § 1313(d)(1)(C), requires that TMDLs "be established at a level necessary to implement the applicable water quality standards with seasonal variations and a margin of safety which takes into account any lack of knowledge concerning the relationship between effluent limitations and water quality." In a stronger formulation:

Uncertainty must be explicitly acknowledged both in the models selected to develop TMDLs and in the results generated by those models. Prediction uncertainty must be estimated in a rigorous way, models must be selected and rejected on the basis of a prediction error criterion, and guidance/software needs to be developed to support uncertainty analysis.

NAT'L RESEARCH COUNCIL, supra note 11, at 10.

38. See HoucK, supra note 37 , at 59 . "Scientific uncertainty is a reality within all water quality programs, including the TMDL program, that cannot be entirely eliminated.... Securing designated 
reasonable demand for reliable scientific data and an unreasonable demand for certainty? Given the variations in sampling and reporting methods among the states, and the perceived need of states for "every manner of technical assistance from monitoring to assessment to enforcement" in order to comply with the TMDL program, it did not seem unreasonable when, for example, the Association of Metropolitan Sewerage Agencies (AMSA) published a survival guide for wastewater agencies that included, as a strategy, challenging in court an impaired water listing by demanding "sufficient reliable scientific data." 39 On the other hand, public "environmental law ... is precautionary, and that precaution requires taking science beyond the dispositive to the reasonable." ${ }^{40}$ From that perspective, the AMSA survival guide appears to be "a litigator's cookbook to identify... methods of limiting or avoiding responsibility." ${ }^{\prime 1}$ As mentioned above, however, the challenge to an impaired water listing (as the AMSA guide recommended) is a different context than a TMDL challenge - the demand for "sufficient

uses is limited... by ... unreasonable expectations for predictive certainty among regulators, affected sources, and stakeholders." NAT'L RESEARCH COUNCIL, supra note 11, at 4 (emphasis omitted). Even beyond the water quality context, "pervasive uncertainty in a variety of dimensions is regularly cited as a defining characteristic of environmental problems." Holly Doremus, Data Gaps in Natural Resource Management: Sniffing for Leaks Along the Information Pipeline, 83 IND. L.J. 407, 446 (2008). As Professor Doremus explains:

Demanding perfection of scientific information is a recipe for paralysis by analysis.... Managers must evaluate, to the best of their ability, the likelihood of obtaining desired scientific information at a reasonable cost within a reasonable time frame. Decisions about how to handle uncertainty should take into account the reducibility or irreducibility of that uncertainty, as well as the risks and costs of various types of error.

Id.

39. See HoucK, supra note 37, at 138-40 (citing AMSA, Evaluating TMDLs . . Protecting the Rights of [Publicly Owned Treatment Works]). As noted by Houck:

The states and TMDL-implicated communities... are alert to... weaknesses in monitoring and assessment and have already signaled their willingness to exploit them. ... Opposing listings as based on inadequate science ("drive-by listings," in the words of one agriculture industry attorney - a characterization that in some cases may not be far from the truth), farm and other nonpoint interests have persuaded states to reduce their submissions on impaired waters to the absolutely proven, with significant results. Incongruous as it may seem in the face of new EPA listing criteria designed to be allinclusive, to err on the side of listing, and to facilitate the use of "all relevant data," many states have actually cut their $\S 303$ (d) lists in half since 1996, relegating hundreds of waters to such categories as "further study," "insufficient information," and only "moderately impaired."

Id. at 138. But see NAT'L RESEARCH COUNCIL, supra note 11, at 5 ("Many [listed impaired] waters... were placed there without the benefit of adequate water quality standards, data, or waterbody assessment.... States should be allowed to move those waters ... back to a preliminary list.").

40. HoucK, supra note 37 , at 140 .

41. Id. at 139-40. For an extensive discussion of the precautionary principle and its relationship(s) with science, see generally Holly Doremus, Precaution, Science, and Learning While Doing in Natural Resource Management, 82 WASH. L. REV. 547, 547-67 (2007). 
reliable scientific data" may well be more reasonable at the listing stage, where states have discretion with respect to water quality standards and assessments of waters thereunder, than at the TMDL stage, when states are compelled to act quickly to correct an acknowledged impairment. One of the purposes of our study of local TMDL controversies, apart from, but central to, our inquiry as to whether and how idealized scientific arguments are strategically used to challenge regulation, was to identify the contours or characteristics, respectively, of reasonable scientific arguments and those arguments that rest on unrealistic scientific expectations in the TMDL context. We recognize that our judgments in this regard are inevitably normative and possibly controversial; others may not draw the same boundaries as we did, but we are confident the discourse concerning unreasonable scientific standards will be enhanced by evaluating actual arguments made in the early stages of actual TMDL controversies. Furthermore, our emphasis was more on the form of arguments than their content; we did not seek to referee the scientific arguments or declare right from wrong. Finally, we acknowledged that the use of idealized arguments is not limited to industry stakeholders, but is available to either side in an environmental dispute. Environmentalists can potentially demand too much-for example, too conservative a margin of safety, or too much certainty regarding reduction of pollutants.

Our effort to identify and analyze idealized arguments, albeit empirical, falls on the side of qualitative rather than quantitative evidence. $^{42}$ We considered coding our data in numerical terms for statistical analysis, but the small sample of TMDL controversiesespecially their variation in terms of how and when the TMDLs were challenged, the number of interested parties involved in challenges (including dischargers such as municipalities or industry, as well as environmentalist groups), the types of relevant documents, the number of arguments made in those documents, and the subjects interviewed without formal surveys-rendered quantitative analysis meaningless. The nuances were such that there would be too many categories for too few examples. ${ }^{43}$ As a means to capture those nuances, however, and not

42. "The word 'empirical' denotes evidence about the world based on observation or experience. That evidence can be numerical (quantitative) or nonnumerical (qualitative); neither is any more 'empirical' than the other." Lee Epstein \& Gary King, The Rules of Inference, 69 U. CHI. L. REV. 1, 2 (2002) (citation omitted).

43. Because we were engaged in content analysis of documents, which often combines qualitative and quantitative methodology by coding the appearance of particular "contents" according to a set of categories, we could have expressed our results in terms of statistical frequency (of types of arguments), but our sample was so small that such results would be misleading. See 
as a "second best" (to the quantitative) approach, we used semistructured interviews and textual analysis, typical of qualitative methodology, to collect data. ${ }^{44} \mathrm{We}$ are aware of the substantial controversies concerning appropriate methodologies for empirical legal scholarship - some claim "rigorous" quantitative empirical methodology is superior to qualitative or theoretical inquiries, ${ }^{45}$ while others associated with "discourse analysis, cultural studies, feminism[,] and postmodern schools of thought" approaches in numerous settings. ${ }^{47}$ In this Article, we attempt to make explicit our assumptions and our category development for coding the data in our study, and to thereby demonstrate the basis for our qualitative interpretations. ${ }^{48}$ For example, we modified our initial definitions of idealized arguments once we began reviewing relevant documents and interviewing interested parties. ${ }^{49}$

In Part II, we describe the structure of our study in detail, identifying our hypothesis, initial methodological issues and limitations, data collection techniques, and coding categories. Part III is a summary of our database of approximately forty technical and scientific arguments in the five TMDL disputes under analysis. The results of our study are discussed in Part IV, and we also consider several implications of the study, including policy considerations regarding the TMDL program

generally RUSSEL A. JONES, RESEARCH METHODS IN THE SOCIAL AND BEHAVIORAL SCIENCES 12132 (2d ed. 1996) (discussing content analysis, coding, and sampling).

44. See Reza Banakar \& Max Travers, Law, Sociology, and Method, in THEORY AND METHOD IN Socio-LEgAL ReSEARCH 1, 14 (Reza Banakar \& Max Travers eds., 2005).

45. See, e.g., id. at 23-24 ("[In Great Britain,] the quest for finding ways of revitalizing empirical legal research comes at a time when... socio-legal research is at the height of its academic popularity and success. This implies that 'rigorous' research is other than the type of research (mainly of the qualitative interpretive kind) currently undertaken by most socio-legal researchers in the UK.").

46. Reza Banakar \& Max Travers, Introduction, in THEORY AND METHOD IN Socio-LEGAL RESEARCH, supra note 44, at xii.

47. See, e.g., Caprice L. Roberts, In Search of Judicial Activism: Dangers in Quantifying the Qualitative, 74 TENN. L. REV. 567 (2007) (expressing concern over quantitative studies of judicial ideology)

48. See JONES, supra note 43, at 121-22 ("Content analysis as a research technique goes beyond normal reading and viewing habits ... in requiring that you be explicit about the criteria you apply in deciding what a text contains and the rules by which you have applied those criteria. 'Being explicit' means making it possible for another person to apply precisely the same criteria in precisely the same manner, and that when they do, they should arrive at precisely the same conclusions about the text in question.").

49. See LAWrence T. ORCHER, CONDUCTING RESEARCH: SOCIAL AND BeHAVIORAL SCIENCE METHODS 41 (2005) ("[Q]ualitative research does not need to be as fully planned in advance and deviations in the plans can not only be tolerated but might be welcomed as well. For instance, semistructured interviews might be used to gather qualitative data. The interviewers might be encouraged to probe in different directions .... [and] the responses of early respondents might lead to modifications in the questions asked of later participants ...."). 
generally. We conclude in Part $\mathrm{V}$ that while idealized scientific arguments recur with some frequency early in TMDL disputes, they do not seem to be particularly effective at that stage in delaying or weakening state and federal efforts to improve water quality.

\section{StRUCTURE OF THE CASE StUdy}

The well-known metaphor of the 'dialogue' between Method and Nature portrays an ideal communicative situation with fixed roles and functions. The Method puts the questions, Nature offers its answers. . . .

There is, though, another possible scenario, where a real dialogue takes place, within a community of scientists. Here, ... . Nature is the actual object of a dispute, rather than being one of its fictitious disputants. "Dialogue,"-far from suggesting an idealized ritualmeans here actual discussion, debate, controversy, or conflict. ${ }^{50}$

\section{A. Background}

In response to the Project on Scientific Knowledge and Public Policy's (SKAPP's) 2006 request for grant proposals, we submitted an initial contact letter describing our proposed study of the use and manipulation of idealized views of science in the TMDL program. We were then invited to submit a full proposal, which was provisionally approved subject to (1) our providing evidence of cooperation from participants in the subject TMDL controversies, and (2) our providing a description of how we would distinguish between reasonable and unreasonable scientific objections in the relevant documents. The Institutional Review Board at our home institution, Villanova University, also requested an explanation of how the notion of idealized arguments could be "operationalized" in an empirical study.

We initially defined "idealized arguments" as those scientific challenges that employed (1) unrealistically high standards for science, ${ }^{51}$

50. Eleonora Montuschi, Review, 45 BRIT. J. PHIL. SCI. 375, 379 (1994) (reviewing Persuading Science: The Art OF Scientific Rhetoric (M. Pera \& W.R. Shea eds., 1991)).

51. See, e.g., Neff \& Goldman, supra note 3, at S81 ("There is broad agreement that regulatory decisions about the environment, safety, and health should be based on evidence. But pressures for ever-increasing documentation, review, and 'sound science' have been used to create unreasonable standards of evidence, interfering with the government's task of protecting the public."); see also Stephen M. Johnson, Junking the "Junk Science" Law: Reforming the Information Quality Act, 58 ADMIN. L. REV. 37, 41 n.7 (2006) (discussing the Information (or "Data") Quality Act of 2001, Pub. L. No. 106-554, §515, 114 Stat. 2763A-153-154 (2000) (guidelines to ensure accurate data)). Sound science initiatives include not only increased demands for data quality and integrity but also 
(2) claims of uncertainty if able to be characterized as unreasonable demands for certainty, ${ }^{52}$ and (3) claims that an opponent's science is interested (e.g., that it is politically or economically biased). ${ }^{53}$ Our premise was that while science generally involves some level of uncertainty, often relies on models based on assumptions and limited data, and is typically funded from a source with some "interest," those aspects do not signal unreliability in the same way substantial flaws in data collection, data interpretation, or methodology might. In short, we were prepared to look for idealized strategies in several local environmental disputes; our hypothesis (based on environmentalist literature) was that such strategies were indeed used to avoid, delay, or weaken TMDLs.

Because we were not confident about where we might find, if at all, evidence of idealizing strategies, we proposed an initial study of one TMDL controversy, looking at the relevant documents (concerning scientific, not legal, disputes) and interviewing regulators and interested parties. Our goal was to adopt procedures for efficiently studying the remaining TMDLs identified as objects of the study.

The five TMDLs we considered were selected because they were the only local TMDLs challenged by stakeholders on scientific grounds. They otherwise involved various pollutants. While all were the subject of formal appeals to the Pennsylvania Environmental Hearing Board, either the TMDLs were withdrawn (two TMDLs) or the appeals were

preferences for empirical, field-tested, and peer reviewed data. See Chris Mooney, Sucker Punch: How Conservatives are Trying to Use a Conflict over Obscure Fish to Gut the Science Behind the Endangered Species Act, LEGAL AFF., May/June 2004, at 24. However, in endangered species protection, for example:

[Some scientists] [r]ead [such] language as a stealthy attempt to ban... reliable techniques ... [ [such as] population modeling, which projects current data into the future and is thus neither exclusively empirical nor field-tested (though the initial data has to come from the field).... "If you're going to say, 'we can't use models,' you might as well shut down the scientific enterprise."

Id. (quoting biologist Gordon Orians, University of Washington).

52. See Michaels \& Monforten, supra note 2, at S41 (listing examples of "manufactured" uncertainty by the lead, chemical, and asbestos industries).

53. We identify claims of interest as idealized because the mere affiliation of a scientist with an interest group does not signal scientific invalidity:

Interest, it seems, is in the eye of the beholder. Those concerned with regulatory abuse... refer to those who have been the recipients of generous grants from the EPA ... as biased or interested scientists... . From the opposite perspective, it is the use of [outside] interest groups to review the quality of the science within agencies that presents the greater challenge[,]... as if interest groups do not rely on legitimate science[;] .. . [In this latter perspective,] "adversarial challenges" [are] the opposite of "expert consensus," [and] scientists are never adversarial.

David S. Caudill, Images of Expertise: Converging Discourses on the Use and Abuse of Science in Massachusetts v. EPA, 18 VILL. ENVTL. L.J. 185, 203-05 (2007). 
withdrawn (three TMDLs). Our goal was not to explore generally how draft TMDLs were created - neither initially, in negotiated settlements, nor through litigation - but rather to determine whether and how parties challenged the science leading up to the final TMDLs. We planned to examine, for the initial (and each subsequent) TMDL, its "load" requirements for the subject pollutant, the agency's technical support documents, public comments on the draft TMDL, any appeals, the technical supporting documents for any appeal, and the results of any appeal. We also planned to supplement our understanding and analysis of documents by interviewing state and federal TMDL supervisors and technical support personnel, as well as stakeholders and litigants (including representatives of municipal and industry dischargers as well as environmental groups), and their technical advisors. Significantly, we recognized that our initial categories of "idealized arguments" might be rejected or modified, and that new categories might be identified.

\section{B. Methodological Issues}

In our attempt to distinguish idealized arguments from reasonable and justifiable ones, we acknowledged that a challenge on the basis of excessive uncertainty, inadequate data, or inappropriate modeling is not necessarily an idealized argument. Genuine scientific evaluation can proceed on the basis that the data is wrong or incomplete (e.g., gaps in the data), or by highlighting questionable assumptions, conflicts of interest, and flaws or errors in the technical supporting documents and models. Nevertheless, we attempted to identify unreasonably high standards and unrealistic demands for certainty or disinterestedness, and we understood such strategies would not be acknowledged or clearly visible in TMDL challenges.

Constructing a definition of an idealized, unreasonable, or too demanding argument turned out to be very difficult. Having identified some arguments that seemed idealized to us, we realized we were evaluating arguments within a particular and narrow context, namely the interactions between stakeholders and regulators just before and just after a TMDL is finalized. In a different context, an argument that seems unreasonable (in response to a TMDL) might be quite appropriate. For example, peer review of a scientific report is a conventional demand prior to publication in a scientific journal and an appropriate postDaubert v. Merrell Dow Pharmaceuticals, Inc. "factor" in judicial 
evaluations of reliability and admissibility. ${ }^{54}$ But in the context of statutorily-mandated and perhaps rushed regulation to reduce water pollution, such a demand might be unrealistic. ${ }^{55}$ Similarly, conducting a formal uncertainty analysis as part of TMDL modeling, rather than simply using a ten percent margin of safety, would improve the reliability of the results; ${ }^{56}$ demanding that level of reliability does not seem unreasonable to a stakeholder facing an expensive modification to

54. See 509 U.S. 579, 593-94 (1993) (noting "factors [that] bear on the inquiry" into the reliability of scientific testimony include testability, low error rate, peer review or publication, and "general acceptance").

55. See generally J.B. Ruhl \& James Salzman, In Defense of Regulatory Peer Review, 84 WASH. U. L.Q. 1 (2006) (detailing how mandatory, rigorous, and inflexible peer review adds high demand on agency resources). This has the potential to drain resources from other decision-making components and also has the potential to impede decision-making overall. Id.

56. Telephone Interview with Ken Reckow, Professor, Department of Environment and Earth Studies, Duke University (Sept. 5, 2007) (discussing how ambiguities in TMDL regulation are likely of concern to the regulated community; one study indicated that 171 of 172 subject TMDLs did not contain formal uncertainty analyses; some modelers have developed methods of formal uncertainty analysis, but these have not achieved widespread implementation); see also PAUL L. FREEDMAN ET AL., WATER ENV'T Res. Found., NAVIGATING THE TMDL PROCEss: Evaluation AND IMPROVEMENTS (2003) (providing a review of 176 TMDLs, of which 103 specified a margin of safety (102 of which were arbitrarily selected, and one of which was based on a calculation of uncertainty), 56 implied a margin of safety, and 17 used no margin of safety or were unclear whether a margin of safety was used); Mark E. Borsuk et al., Predicting the Frequency of Water Quality Standard Violations: A Probabilistic Approach for TMDL Development, 36 ENVTL. SCI. \& TECH. 2109, 2114 (2002) (Limited samples to infer water quality characteristics introduce uncertainty, and current TMDL models under-represent the dynamics of the system; authors propose a probabilistic approach to enhance prediction of standard violations). The authors explain:

[T] he common practice, when attempting to use complex simulation models for decision support, [is to select] the margin of safety using arbitrary safety factors or conservative model assumptions. However, such a practice obscures the underlying basis for the margin of safety and amounts to making decisions 'in the dark.' If, on the other hand, a formal uncertainty analysis is performed, in which model results are expressed as the degree of confidence that a standard will be met for any given pollutant loading level, then decision-makers simply need to choose the percent reduction that corresponds to their desired level of confidence.

Id. at 2114. For a similar analysis, see Vladimir Novotny, Simplified Databased Total Maximum Daily Loads, or the World is Log-Normal, 130 J. ENVTL. ENG'G. 674 (2004). See also David W. Dilks \& Paul L. Freedman, Improved Consideration of the Margin of Safety in Total Maximum Daily Load Development, 130 J. ENVTL. ENG'G. 690, 690-91 (2004) (“[T]he margin of safety component of TMDLs is not being addressed rigorously in most TMDLs currently being developed . . and ... the approaches currently used vary widely (and arbitrarily) on a site-specific basis.... [The problems are] (1) limited practical experience in defining the uncertainty in the TMDL calculations; (2) absence of information regarding the degree of protection provided by the margin of safety; and (3) data-poor/high-uncertainty situations that can result in MOS values so large as to make implementation impractical.... [because] most stakeholders... will demand that extensive pollution control efforts be based upon scientific understanding gained from a sufficient amount of site-specific data."). 
meet new discharge criteria. ${ }^{57}$ Yet is it reasonable in the context of urgently needed TMDL implementation?

The question concerning appropriate methodologies in various contexts was raised by Professor J.B. Ruhl in a recent article focused on endangered species protection. ${ }^{58}$ Ruhl contrasts the "Scientific Method" he associates with rigorous burdens of proof, probing peer reviews, and strong data, with the Professional Judgment Method that "prevails in administrative law":

Where the costs of the Scientific Method are not justified, or the data needed to complete it are unavailable, we might feel comfortable relying on experts in fields relevant to the subject matter of the decision, whose experience and expertise we believe will allow them confidently to fill in the gaps that prevent competent use of the Scientific Method. ${ }^{59}$

Ruhl also equates the Professional Judgment Method to the conventional standard of review under the Administrative Procedure Act: ${ }^{60}$ "considerable deference to the agency's decision," but a probing review to ensure that the decision is not arbitrary, capricious, an abuse of discretion, or otherwise unlawful. ${ }^{61}$ The decision is arbitrary and capricious if the agency relies on inappropriate factors, fails to consider an important aspect of the problem, offers a justification running counter to the evidence or that is implausible, or fails to articulate a rational explanation for its action. ${ }^{62}$ "Put simply," Ruhl concludes, "the agency has failed to exercise properly its professional judgment...."63 The implication is that the Scientific Method, "which would render

57. For example, Smithfield Beef Group complained that the Skippack Creek TMDL would require an estimated $\$ 150,000$ capital expenditure and $\$ 75,000$ annual costs to comply. EPA, COMMENT RESPONSE DOCUMENT FOR THE SKIPPACK CREEK TMDL, 6, cmt. 02-01 (Apr. 15, 2003) [hereinafter SKIPPACK COMMENTS/RESPONSES]. The EPA's response was that costs of implementation are not considered. $I d$.

58. See J.B. Ruhl, The Battle over Endangered Species Act Methodology, 34 ENVTL. L. 555, 559 (2004).

59. Id. "[M] any decisions [under the Endangered Species Act of 1973, 16 U.S.C. §§ 1531-44 (2006)] involve questions of biological science for which the available scientific database is either sparse or inconclusive. By demanding that the agencies nonetheless reach conclusions under strict deadlines, the [Act] sets up a methodological quandary." Id. at 560.

60. 5 U.S.C. $§ 706$ (2006) (“[T]he reviewing court shall ... set aside agency action, findings, and conclusions found to be ... arbitrary, capricious, an abuse of discretion, or otherwise not in accordance with law [or] ... unsupported by substantial evidence in a case ... reviewed on the record of an agency hearing ....").

61. Ruhl, supra note 58, at 578 (citing Citizens to Pres. Overton Park, Inc. v. Volpe, 401 U.S. 402, 415 (1971) (referring to a "thorough, probing, in-depth review")).

62. Id. (citing Motor Vehicle Mfrs. Ass'n v. State Farm Mut. Ins. Co., 463 U.S. 29, 43 (1983)).

63. Id. 
[Endangered Species Act] decision-making more like [a] Ph.D. dissertation defense[], ${ }^{, 64}$ is not the appropriate standard.

The tension highlighted by Ruhl is not between science and something else, such as mere opinion, as Ruhl's contrast of "professional judgment" with "scientific method," or my brief summation of his views, might suggest. Science is, in the abstract, the foundation for environmental regulation, but the reality is that science comes in many forms. Ruhl and others have spoken in terms of levels of confidence, ${ }^{65}$ and while "sloppy, filtered, or haphazard evidence" is not enough to withstand judicial review, ${ }^{66}$ something short of the "very high level of confidence" associated with the "norms of research science" seems appropriate for environmental regulation. ${ }^{67}$ This framework has been described as balancing "the epistemic objective against relevant nonepistemic objectives" in governmental fact-finding:

The epistemic objective is to produce findings of fact that are as accurate as possible and that are warranted by the evidence legally available to the factfinder. The non-epistemic objectives include... administrative efficiency... [and] public health.... [, which] influence... what standard of proof the factfinder should use in selecting a finding.... ${ }^{68}$

\section{Id. at $560-61$.}

65. See id. at 555 ("One basis on which we might choose how to go about making decisions is the level of confidence we wish decisions to enjoy."); see also Holly Doremus \& A. Dan Tarlock, Science, Judgment, and Controversy in Natural Resource Regulation, 26 PUB. LAND \& RESOURCES L. REV. 1 (2005).

Environmental law is ... indebted to science... both as the justification for environmental law and as the means for fairly administering it.

$\cdots$

... Unless science can provide some level of confidence that management actions are both necessary and effective, those decisions will be widely perceived as unfair. The key question, not yet answered, is just how much confidence should be expected.

Id. at 1-2; see also Borsuk et al., supra note 56, at 2114 (noting that decision makers need to determine their desired level of confidence and choose percent reductions that directly correspond).

66. Ruhl, supra note 58, at 582.

67. See Holly Doremus, The Purposes, Effects, and Future of the Endangered Species Act's Best Available Science Mandate, 34 EnVTL. L. 397, 439 (2004) [hereinafter Doremus, The Purposes, Effects, and Future].

68. Vern R. Walker, Epistemic and Non-epistemic Aspects of the Factfinding Process in Law, 5 J. PHIL., SCI. \& L. 1, 1-2 (Mar. 2005).

Factfinding in law is always pragmatic, in the sense that it always occurs in a context in which governmental action is at stake. ...

The epistemic objective ... is to ensure that the factfinder will be accurate .... But the factfinding process cannot be divorced from the pragmatic context in which it occurs .... The non-epistemic objectives therefore influence... when the factfinder should be allowed to find that the available evidence "adequately supports" a finding .... 
In the context of endangered species protection, for example, "[w]hen faced with uncertain data, we must decide how much certainty to require - that is, what level of confidence we want to have in our decision-before altering the status quo. The question essentially is what burden of proof we want to impose on the wildlife agencies." 69 The issue of the "burden of proof" on agencies, as contrasted with the burden of proof on those challenging regulations, became important for our definition of an idealized scientific argument on the part of a stakeholder challenging a TMDL. Specifically, when is it unreasonable to demand more certainty in TMDL science?

While the conventional framework for judicial review of federal agency actions combines (1) a burden on the challenger to demonstrate an error, ${ }^{70}$ with (2) judicial deference to agency discretion ("narrow" standard of review; presumption of validity), ${ }^{71}$ there is, in the context of challenges to science-based regulation, a corresponding (1) burden on the agency to justify its decision, combined with (2) a "searching and careful" judicial inquiry into the agency's findings of fact. ${ }^{72}$ Whether the agency's burden is called a burden of proof, or simply a requirement to meet "a specific threshold level of scientific information to support regulatory decisions" (including "the appropriate level of scientific

Id. at $1-2$.

69. Doremus, The Purposes, Effects, and Future, supra note 67, at 439.

70. See, e.g., Citizens Comm. Against Interstate Route 675 v. Lewis, 542 F. Supp. 496, 521 (S.D. Ohio 1982) (noting that in order to overturn an agency decision, plaintiffs must show the "decision was a "clear error of judgment"”); Chung v. Park, 377 F. Supp. 524, 530 (M.D. Pa. 1974) (declaring "[t]he placement of the burden of production on [the challenger] did not deprive [the challenger] of 'due process"'), aff'd, 514 F.2d 382 (3d Cir. 1975).

71. See, e.g., Sierra Club v. Hankinson, 939 F. Supp. 865, 869 (N.D. Ga. 1996) ("The APA's standard of review is narrow and presumes that agency action is valid . ...”); United Elec., Radio \& Mach. Workers of Am. v. NLRB, 986 F.2d 70, 74 (4th Cir. 1993) (noting that an agency decision is only revised "if the record is 'so compelling that no reasonable factfinder could fail' to disagree" (quoting INS v. Elias-Zacarias, 502 U.S. 478 (1992))).

72. See Citizens to Pres. Overton Park, Inc. v. Volpe, 401 U.S. 402, 416 (1971). Thus in the "Benzene" opinion, Industrial Union Department, AFL-CIO v. American Petroleum Institute, the burden was on OSHA "to show, on the basis of substantial evidence, that it is at least more likely than not that long-term exposure to $10 \mathrm{ppm}$ of benzene presents a significant risk of material health impairment." 448 U.S. 607, 653. "OSHA is not required to support its finding that a significant risk exists with anything approaching scientific certainty. Although the Agency's findings must be supported by substantial evidence, 29 U.S.C. $\S 655(\mathrm{f}), \S 6(\mathrm{~b})(5)$ specifically allows the Secretary to regulate on the basis of the "best available evidence." Id. at 656 . Whether the "best available evidence" standard adds any higher burden on an agency is not clear. See Ruhl, supra note 58, at 582; see also Doremus \& Tarlock, supra note 65, at 6 (noting it is not clear that science mandates add any additional level of constraint). Nevertheless, "even in the absence of any explicitly legislative scientific mandate[s]," today's "ordinary APA review requires that agencies provide some scientific justification for highly technical decisions." Id. at 4. 
certainty or caution"), ${ }^{73}$ agencies must justify their science, ${ }^{74}$ offer adequate reasons for their decisions, ${ }^{75}$ and produce evidence. ${ }^{76}$

Under Pennsylvania's Administrative Agency Law, by comparison, findings of fact made by an agency also must be supported by substantial evidence. ${ }^{77}$ The "arbitrary and capricious" standard does not appear in the Pennsylvania Act, but does appear in judicial opinions under the Act ${ }^{78}$ along with the "presumption that the actions of public officials are within the limits of their discretion." ${ }^{, 79}$ In a PaDEP environmental action appeal to the Environmental Hearing Board, the appellant bears the burden of proof ${ }^{80}$ but an agency must support its findings with substantial evidence. $^{81}$ Upon judicial review of a Board decision, findings of fact

73. Doremus, The Purposes, Effects, and Future, supra note 67, at 416.

74. See Natural Res. Def. Council, Inc. v. Muszynski, 268 F.3d 91 (2d Cir. 2001) (holding that the EPA had to explain how they took seasonal variations into account, produce evidence to support a ten percent margin of safety, and show that allowing the state to use aesthetic water quality standards to formulate TMDLs for phosphorus in waterbodies was not arbitrary and capricious).

75. See Am. Mining Cong. v. U.S. EPA, 907 F.2d 1179, 1188 (D.C. Cir. 1990) (concluding that some of EPA's listings of metal smelting wastes as hazardous were based on reasoned decisionmaking, but some were not). Agency actions can also be reversed if the agency failed to consider substantial arguments or respond to relevant and significant comments in an agency proceeding. See ABA, A Blackletter Statement of Federal Administrative Law 34 (2004).

76. See Sierra Club, 939 F. Supp. at 869-72 (holding in a summary judgment action, moving party can meet its burden by showing the agency has no evidence to support its position; at that point the burden shifts to the agency).

77. 2 PA CONS. STAT. $\$ 704$ (2008).

78. See Deane v. Bd. of Adjustment of Zoning Bd. of Borough of Edgeworth, 94 A.2d 112, 114 (Pa. Super. Ct. 1953) (recognizing that arbitrary and capricious actions will be reversed); Cardiac Science, Inc. v. Dep't. of Gen. Servs., 808 A.2d 1029, 1033 (Pa. Commw. Ct. 2002) (“'Courts will not review the action of governmental bodies or administrative tribunals involving acts of discretion in the absence of bad faith, fraud, capricious action, or abuse of power." (quoting Kimmel v. Lower Paxton Twp., 633 A.2d 1271, 1274 (Pa. Commw. Ct. 1993))). Significantly, "some commentators would agree that [it] is unclear whether 'arbitrary and capricious' actually means anything different than 'substantial evidence."' Jerry Mashaw, Legal Control of Administrative Policymaking: The "Judicial Review Game", reprinted in PETER SCHUCK, Foundations of AdMINISTRATIVE LAw 242 (2d ed. 2004).

79. Snelling v. Dep't. of Transp., 366 A.2d 1298, 1304 (Pa. Commw. Ct. 1976).

80. See 25 PA. CODE $\S 1021.122$ (c) (2006) ("A party appealing an action of the Department shall have the burden of proof .... (1) When the Department denies a license, permit, approval or certification. (2) When a party who is not the recipient of an action by the Department protests the action. (3) When a party to whom a permit approval or certification is issued protests...."). Interestingly, the PaDEP regulations no longer state that a challenger of a TMDL has the burden of proof to show that the TMDL does not meet requirements. See Law of July 1, 1933, 25 PA. CodE $\S$ 96(4)(L) (repealed 1937); see also 30 Pa. Bull. 5913, 6068 (Nov. 18, 2000) ("The proposed subsection (1), placing the burden of proof on a person who challenges a TMDL, is deleted in response to comments."); Telephone Interview with Martha Blasberg, Supervisory Counsel, PaDEP (Feb. 13, 2007) (stating it is likely PaDEP would take the position that the burdens are the same); Berks County v. Dep't Envtl. Prot., 894 A.2d 183, 191 (Pa. Commw. 2006) (acknowledging that a party protesting issuance of a permit has the burden of proof to show issuance was arbitrary or an abuse of discretion), appeal denied, 907 A.2d 1104 (Pa. 2006).

81. Smedleh v. PaDEP articulated the Board's standard for de novo review as "whether the 
must be supported by substantial evidence. ${ }^{82}$ There is precedent for the notion that the Board shifts the burden of proof to PaDEP once "credible" expert scientific evidence shows PaDEP's actions have a negative effect on the environment, ${ }^{83}$ but this is arguably misleading. ${ }^{84}$ Only the "burden of going forward with the evidence" shifts, that is, the burden of production. ${ }^{85}$ In any event, a regulatory action by PaDEP will require substantial supporting evidence to withstand judicial review.

This brief foray into standards of review in administrative law, the complexities of which are far beyond the scope of this article, ${ }^{86}$ is necessitated by the question of what types of scientific arguments should be considered unreasonable or too demanding in the context of TMDLs. Consider the EPA's own 2002 TWENTY NEEDS REPORT: HOW RESEARCH CAN IMPROVE THE TMDL PROGRAM, ${ }^{87}$ which recommends improving the scientific quality of existing TMDLs, analytical modeling, uncertainty analysis (calculated instead of using subjective margins of safety), monitoring programs, and water quality standards (numeric rather than narrative) ${ }^{88}$ Although the report "does not represent or modify EPA's TMDL program policy or guidance and is limited to

findings upon which the DEP based its actions are correct and whether DEP's action is reasonable and appropriate and otherwise in conformance with the law." Adjudication at 30, No. 97-253-K (Pa. Envtl. Hear'g Bd. Feb. 8, 2001).

82. See, e.g., Commonwealth Dep't of Envtl. Res. v. City of Lebanon, 393 A.2d 381, 384 (Pa. 1978) ("The [Department of Environmental Resources]... produced evidence that fluoride treatment has been successfully practiced in this country for decades ... without producing any ill effects."); see also Oley Twp. v. PaDEP, 710 A.2d 1228, 1230 (Pa. Commw. Ct. 1998) (findings of fact must be supported by substantial evidence).

83. Concerned Residents of the Yough, Inc. v. Dep't of Envtl. Res., 639 A.2d 1265, 1269 (Pa. Commw. Ct. 1994) (holding that when an objector to DEP action produces credible evidence, the burden of proof shifts to DEP to justify its action); Marcon, Inc. v. PaDEP, 462 A.2d 969, 971 (Pa. Commw. Ct. 1983).

84. See Ainjar Trust v. PaDEP, 806 A.2d 482, 488 (Pa. Commw. Ct. 2002).

85. Marcon, Inc., 462 A.2d at 971 . The burden of proof is comprised of the burden of production and the burden of persuasion. Riedel v. County of Allegheny, 633 A.2d 1325, 1329 n.11 (Pa. Commw. Ct. 1993). The burden of persuasion never shifts, but the burden of production of evidence to support a particular proposition might. Id.; see also In re Loudenslager's Estate, 240 A.2d 477, 482 (Pa. 1968) (Roberts, J., dissenting) (noting that the burdens of persuasion and production may be allocated to different parties).

86. See generally Peter L. Strauss, Overseers or "The Deciders"-The Courts in Administrative Law, 75 U. CHI. L. REV. 815 (2008) (providing an overview of contemporary debates and leading cases concerning the standard of review in administrative law). Likewise, we do not address in this Article the ethical duties of attorneys with respect to idealized scientific arguments. See generally David S. Caudill, Legal Ethics and Scientific Testimony: In Defense of Manufacturing Uncertainty, Deconstructing Expertise, and Other Trial Strategies, 52 VILL. L. REV. 953 (2007) (arguing that because the ethical standard only prohibits presentation of testimony known to be false, there is no ethical prohibition against presenting questionable scientific expertise).

87. U.S. EPA, PUBL'N. No. 841-B-02-002, available at http://www.epa.gov/owow/tmdl /20needsreport_8-02.pdf.

88. See id. at 7-31. 
analysis and recommendations concerning scientific issues," ${ }^{, 89}$ it constitutes a smorgasbord of scientific shortcomings that would invite any TMDL stakeholder to challenge ongoing TMDL issuances. Given National Research Council backing for such recommendations, ${ }^{90}$ it would not seem unreasonable to criticize TMDL science. On the other hand, the TMDL program continues to develop in the face of Clean Water Act mandates, so it is easy to see why TMDLs are created despite such potential challenges. In this study, we encountered TMDLs that reflect the shortcomings of the current program, with all of its uncertainties and limitations in terms of resources and data. We decided not to speculate on whether the TMDLs could withstand judicial scrutiny as based on substantial evidence, but rather to identify arguments that seem unreasonable early in the comment phase, given the current uncertainties and existing limitations upon data and resources. For example, when we identify as unreasonable the criticism of a ten percent margin of safety (or lack of site-specific data) because the critic fails to suggest an alternative analysis, we are not suggesting that the burden of proof on a party challenging the TMDL requires submitting an alternative analysis; rather, we are suggesting that such criticism is neither helpful nor constructive. When such criticisms are raised and the response of the EPA or PaDEP is simply to confirm that the margin of safety (or the amount of existing data) is scientifically adequate, the subtext of the response seems to be, "Of course, it would be better to conduct a formal uncertainty analysis (or to collect more data), but we cannot interminably delay the TMDL program." Further examples will be offered in this Article, but we should clarify that we are not addressing the status of an argument identified as idealized in the context of judicial review of EPA or PaDEP actions. Nevertheless, an idealized argument may well be viewed by an agency as insignificant or irrelevant, or by a court as unpersuasive in deciding whether agency action is supported by substantial evidence, precisely because of the compulsory nature of TMDLs (i.e., regardless of the science in hand, TMDLs must be created, which counsels against a stringent scientific standard and in favor of adaptive implementation).

For example, in the litigation that followed the EPA's approval of the Anacostia TMDL, the federal district court's memorandum opinion

89. Id. at $\mathrm{v}, 1$.

90. See generally NAT'L RESEARCH COUNCIL, supra note 11, at 4 (noting the National Research Council has recommended changes in the TMDL process "with an understanding that without such changes, the TMDL program will be unable to incorporate and improve upon the best available scientific information"). 
referred to the argument by Friends of the Earth that the EPA's margin of safety did not take "into account any lack of knowledge concerning relationship between effluent limitations and water quality." "91 The court explained that the "plaintiff misconstrues the threshold for satisfying a margin of safety requirement" all the relevant evidence because determining a margin of safety is a "matter of administrative policy and scientific uncertainty." 93 In other words, the mere presence of uncertainty is not a flaw, and the plaintiff was setting an idealized standard for managing uncertainty. Significantly, this argument highlights the use of uncertainty claims by environmentalist groups - idealization is a strategy available to everyone, not only to those stakeholders subject to environmental regulation. Another example of an environmentalist challenge to a TMDL is found in Muszynski. ${ }^{94}$ In that case, the court seemed to view the challenge as idealistic - the ten percent margin of safety was supported by substantial evidence and the use of aesthetic water quality standards to regulate phosphorus in water supply waterbodies was not arbitrary or capricious. $^{95}$ While such cases strongly suggest that idealized arguments will not work in challenges to agency action, this study does not address that phenomenon (except to note that the effect of idealized arguments is quite visible when discussed in published opinions). In the initial stakeholder responses to a TMDL, our limited goal was to identify arguments that seemed to make unreasonable or unrealistic demands on the EPA and/or PaDEP, and to consider their capacity for causing delay or withdrawal of the TMDL.

91. Friends of the Earth v. U.S. EPA, 346 F. Supp. 2d 182, 198-99 (D.D.C. 2004) (granting defendant EPA's motion for summary judgment), rev'd, 446 F.3d 140 (D.C. Cir. 2006). The margin of safety must take "into account any lack of knowledge concerning the relationship between effluent limitations and water quality." Id. (citing 33 U.S.C. $§ 1313(\mathrm{~d})(1)(C)(2000) ; 40$ C.F.R. § 130.2(i) (1989)).

92. Id. at 199 .

93. Id. (emphasis added). That is, the Clean Water Act mandate to include a margin of safety, indicating Congress expected states and the EPA to proceed in the face of uncertainty, factors into the agency's burden of proof.

94. Nat'l Res. Def. Council, Inc. v. Muszynski, 268 F.3d 91 (2d Cir. 2001).

95. See id. at 101, 103. Note that most environmentalist challenges to TMDLs focus on margins of safety and try to make the TMDL more stringent, while industry stakeholders focus more on the relationship between the TMDL and environmental processes in an effort to make the TMDL less stringent. 


\section{Summary of Findings}

We did not find any significant examples of obvious or explicit idealizations of science, such as the arguments that (1) the TMDL is inappropriate because some level of uncertainty rendered it imperfect, or (2) an opponent's scientific arguments are invalid due to bias and affiliation with a party. Everyone realizes there are uncertainties in the TMDL process ${ }^{96}$ and that almost every scientific report is commissioned by an entity or individual with some interest in the outcome of the controversy. In some challenges to TMDLs, however, we did identify idealizations that might be called subtle or implicit:

(1) Arguments that there is "too much uncertainty" in the development of the TMDL, or that the "margin of safety is too conservative." Such arguments imply there is some threshold of science left unsatisfied, but no such threshold is offered. By failing to specify how much uncertainty is tolerable, or what an appropriate margin of safety might be, the argument devolves into a demand for an imaginary or unknown standard. ${ }^{97}$

(2) Arguments that fail to consider the effect of an alleged error or the magnitude of the effect. As there are no explicit claims that the science behind a TMDL decision must be perfect, the general argument that there is too great an error appears to be a reasonable objection. However, when a party argues a model is "inappropriate" (e.g., an algae level analysis based on lakes is applied to streams), there is sometimes no explanation as to why the model is inappropriate (e.g., does the lake model over-predict or under-predict algae growth?), or what the effect of a different model would be on the water management decision, including the magnitude of the effect (e.g., the effect may be minimal). If effect and magnitude are not considered by the challenger, then the challenge implies that any imperfection renders the governing model inappropriate.

96. See SHABMAn ET AL., supra note 30, at 13-23. The authors detail the uncertainty that exists at several stages of the TMDL process. At the stage of listing impaired waters, "there will always be analytical uncertainty [as a result of data limitations] in establishing whether water quality criteria are being met and in assessing the effectiveness of implementation in securing" water quality standards. Id. at 14. At the TMDL stage, "the level of uncertainty in TMDL evaluations is rarely well defined and often large," and predictions from simple models (not reflecting the "full complexity of a situation"), as well as from complex models with limited data, may be uncertain. Id. at 17. At the implementation stage, one problem is the "large uncertainty in quantifying the contributions of and effectiveness of controls on nonpoint sources." Id. at 19. At later stages where there is attainability uncertainty, "the uses and criteria appropriate and attainable for a particular water body may be uncertain." Id. at 20.

97. See supra note 56 and accompanying text (discussing the distinction between margins of safety and formal uncertainty analyses). 
We identified this as a form of idealization because any error provides a basis for opposing a TMDL. ${ }^{98}$

Of course, this form of argument may not signal an idealization or necessarily indicate an invalid argument. It is likely a stakeholder complaining about a model may not have the opportunity to run a new model, and therefore cannot test the effect and magnitude of an alternative analysis. Nevertheless, we found examples of some basic objections associated with calibration, analytic parameters, sample value averaging, and the use of non-local data that neither addressed nor speculated upon the effect or magnitude of the alleged error.

(3) Arguments that fail to consider whether the science supporting a TMDL is the best alternative despite its error or uncertainty. For example, numerous technical reports commissioned by stakeholders questioned procedures in the TMDL analysis without indicating a preferred process. Again, due to practical constraints on the part of regulators and stakeholders, the form of this argument in some cases simply reflects time and resource limitations rather than idealization. Nevertheless, by failing to suggest better alternative analyses, some arguments end up impliedly demanding perfection and therefore idealize the capacity of science to produce certainty.

TMDL controversies can be conceived as a process in which justifiable (or reasonable) scientific arguments and idealized (or unrealistic) scientific arguments alternatively appear. For example, when an error or uncertainty is identified in a TMDL document, the argument that such a fundamental flaw renders the TMDL scientifically unsound may or may not be an idealization - if the demand is that TMDLs must be free from minor errors or moderate uncertainty, the capacity of science is idealized. But if the argument is that the error or uncertainty is too great, then we believe three questions should follow:

(1) Is there another procedure or method that would produce less error or uncertainty? If so, the flaw is the failure to use that procedure or method. If not, then the objection to error or uncertainty is impliedly an idealization of science as error free and certain.

98. See Elizabeth Mishalanie \& Charles Ramsey, Obtaining Trustworthy Environmental Data: Sampling and Analysis Issues, 13 NAT. RESOURCES \& ENV'T 522 (1999). Although the authors focus on the frequent need for property owners or buyers to know the level of chemical contamination in soil, their discussion of the inevitability of error in measurement is applicable to the TMDL program. Because all "measurements are actually estimates" that include potential bias (over- or under-estimation) and variability (scatter or imprecision) errors, "the true accuracy of any measurement is something that can never be known." Id. at 522. Moreover, even when sampling errors are negligible, samples of the same material sent to multiple independent laboratories will result in varying determinations of the average concentration of a chemical. See id. at 525-26. 
(2) Does the flaw adversely affect the challenger, i.e., what is the effect on the water management decision? If the identifiable effect of the flaw is to set unjustifiable restrictions on the regulated party, then the demand for (or production of) more data and corrected measurements is reasonable. If, on the other hand, a party demands more data without knowing (or at least speculating upon) the effect more data would have on the TMDL, the argument is reduced to a claim that the flaw is the presence of error or uncertainty, which idealistically assumes only errorfree science is adequate.

(3) What is the magnitude of the effect of the flaw? That is, what is the practical effect on the water management decision? For example, if a model for algae growth omits a variable for shade from sunlight, then a challenge based on the significance of this omission for the TMDL would be reasonable. If, however, the omission is highlighted as a per se indicator of a flawed analysis, without showing (or speculating upon whether) the effect is significant, ${ }^{99}$ then science has been idealized as an enterprise that considers every variable.

By far, most of the scientific arguments that appeared in the subject TMDL controversies were reasonable and justifiable. For example, claims of zero correlation between a nutrient and algae production do not inherently idealize science-an alternative is offered (e.g., no regulation), along with a detrimental effect (e.g., unnecessary load reduction) and a consideration of magnitude (e.g., the waterway is completely insensitive to changes in nutrient loading). Therefore, claims of unachievable outcomes are inherently reasonable (e.g., no amount of reduction of a nutrient will produce a specified water quality outcome). However, we identified numerous examples of claims that did not consider or answer the foregoing questions concerning better alternatives, the effects of alleged errors, and magnitude of the effects. While it is not unreasonable to identify, define, examine, and criticize flaws in the TMDL process, the mere presence of a flaw does not in itself render the TMDL scientifically unsound. To argue it does is impliedly premised on the idealized notion that science is never erroneous or uncertain.

Using the foregoing template, we surveyed the technical and scientific objections to the five TMDLs in our study and constructed a

99. We refer here to practical significance, as when a small error may have no practical effect (all models have errors but are nevertheless potentially useful) and should therefore not serve as grounds for opposition. We recognize that "significance" is a term of art, and we are not referring, for example, to statistical, economic, or ecological significance. 
database and set of categories for coding the arguments we considered idealized.

\section{CATEGORIZING THE DATA}

[Alexander Von] Humboldt tilted his head back... The understanding of the cosmos had made great strides.... The end of the road was in sight, the measuring of the world almost complete. ... Science would bring about an era of the general good, and who could know if one day it might even solve the problem of death. ${ }^{100}$

\section{A. Five TMDL Controversies}

We began this study by focusing on the TMDL for the Skippack Creek Watershed in Montgomery County in southeastern Pennsylvania, which was issued by the EPA. The efforts to address excessive algae in Skippack Creek (listed as impaired in 1996, 1998, 2002, and 2004) resulted in a brief scientific controversy beginning in 2004 with a report to PaDEP, ${ }^{101}$ followed by an informational meeting, a pre-public meeting of the stakeholders, a draft TMDL for public comment, the final TMDL, an appeal to the Pennsylvania Environmental Hearing Board, and a withdrawal of the TMDL in 2007 (to be re-issued in the near future). ${ }^{102}$

100. Daniel Kehlmann, Measuring The World 204 (Carol Brown Janeway trans., 2006).

101. On December 11, 2004, Dr. Hunter Carrick from Penn State University (under contract with PaDEP) submitted a report summarizing his algae sampling and concluded that the Skippack Creek was saturated with nutrients and environmentally degraded. Hunter J. Carrick, Using Periphyton to Estimate TMDL Endpoints and Assess Impairment in an Urban-Suburban Stream (Skippack Creek, Pennsylvania), in EPA Region III, TOTAL MAXIMUM DAILY LOAD FOR SKIPPACK CREEK, MONTGOMERY COUNTY, PENNSYlVANIA app. D. (2005) [hereinafter Carrick's Report]

102. A public meeting was held December 15, 2004, to review the technical data with the stakeholders. Notice of Appeal, Lower Salford Twp. Auth. v. PaDEP, No. 2005-100-K (Pa. Envtl. Hearing Bd. May 16, 2005). On January 20, 2005, the draft TMDL was sent out for public comment, and a public meeting was held on February 16, 2005. EPA Region III, TOTAL MAXIMUM DAILY LOAD FOR SKIPPACK CREEK, MONTGOMERY COUNTY, PENNSYLVANIA 68 (2005) [hereinafter SKIPPACK CREEK TMDL]. The comments and EPA responses were published on April 15, 2005. The final TMDL, issued on April 9, 2005, is seventy-one pages long (with twenty-two pages of appendices), and is supported by an eighty-three-page modeling report (with nineteen pages of appendices). See SKIPPACK CREEK TMDL, supra. Eleven point source dischargers were affected, seven of which are municipal sewage dischargers. As an example, the Borough of Souderton had an NPDES permit for $2 \mathrm{mg} /$ liter of total phosphorus, and the TMDL reduced its allowable total phosphorous effluent limit to $.24 \mathrm{mg} / \mathrm{liter}$ and its allocated load to $1463 \mathrm{lbs} / \mathrm{yr}$. See id. at 63 . The Borough filed its appeal on October 31, 2006. Notice of Appeal, Borough of Souderton v. PaDEP, No. 2006-240-K (Pa. Envtl. Hearing Bd. Oct. 31, 2006). This followed an appeal by two other municipal authorities on May 16, 2005. Notice of Appeal, Lower Salford Twp. Auth., supra. On January 8, 2007, the EPA announced its intention to withdraw the TMDL due to an error in one of the scientific papers on which Dr. Carrick had relied. See Carrick's Report, supra note 101; Status Report at 1-2, Lower Salford Twp. Auth. v. PaDEP, No. 2005-100-MG (Pa. Envtl. Hearing Bd. Apr. 6, 2007). 
Scientific arguments appear not only in the comments and appeal documents, but in four technical reports commissioned by stakeholders and submitted to PaDEP on November $15,2006 .{ }^{103}$

The second controversy in our study followed the issuance of the Conestoga Headwater TMDL, which PaDEP prepared in August 2004 for submission to the EPA. ${ }^{104}$ Four point source dischargers were identified, and a nineteen percent reduction in phosphorus loading was required to meet water quality standards. ${ }^{105}$ Appeals were filed, consolidated in June 2005, and withdrawn in November 2006. ${ }^{106}$ The third controversy followed the EPA approval of PaDEP's TMDL for portions of Neshaminy Creek on December 9, 2003; seven point source dischargers filed appeals, and the TMDL was withdrawn in 2007 for the same reason the Skippack Creek TMDL was withdrawn. ${ }^{107}$ The fourth controversy followed the EPA's issuance of the December 15, 2003 TMDL for polychlorinated biphenyls (PCBs) in zones 2-5 of the Tidal Delaware River; the health concern was the potential carcinogenic effects of eating contaminated fish found in the Delaware Estuary. ${ }^{108}$ An appeal was filed with the Pennsylvania Environmental Hearing Board by

103. See Frank X. Browne, F.X. Browne, Inc., Review and Comment on the [Skippack CREEK TMDL \& CARRICK'S REPORT], 2-20 (2006); THOMAS W. GALLAGHER, HYDROQUAL, INC., A Review of [CARrick's Report] 2-7 (2006); X. SEAN Zhang, Carroll EnG'G Corp., A REVIEW and Opinion on Data ANALysis and the SElection of Literature Regression Models IN [THE SKIPPACK CREEK TMDL] 5-11 (2006). A fourth report was filed by James S. Cosgrove, but was not considered in this Article.

104. The Conestoga River headwater is the most upstream 1.2 miles of the river in Berks County, Pennsylvania, identified in Pennsylvania's 1996 § 303(d) list as impaired by nutrients, organic enrichment, and low dissolved oxygen. See PaDEP Central Office, Total Maximum DAILY LOAD (TMDL): CONESTOGA HEADWATERS LANCASTER/BERKS COUNTY, OFFICE OF WATER MANAGEMENT, 1 (2004) [hereinafter CONESTOGa HEADWATERS TMDL]. The TMDL was developed using Black Creek in Lancaster County, Pennsylvania as a reference watershed. $I d$. at 9.

105. Id. at 1 .

106. See infra notes $148-49$.

107. See 37 PA. Bull. 33, (Aug. 18, 2007); PaDEP, Total MaXimum Daily Load (TMDL) ASSESSMENT FOR THE NESHAMINY CREeK WATERSHEd IN SOUTHEAST PENNSYlvaNia (2003) [hereinafter NeShAminy CREeK TMDL]. The TMDL will likely be re-issued, like the Skippack Creek TMDL, in the near future; Dr. Carrick had also done the endpoint estimates final report leading up to the Neshaminy Creek TMDL, and the same erroneous article had been relied upon. See Carrick's Report, supra note 101, HUNTER J. CARRICK, TMDL ENDPOINT ESTIMATES FOR [AN] Urban-Suburban Stream Based Upon In-Stream Periphyton Assemblages (NeshaminY CREEK, PENNSYLVANIA) (2005).

108. The estuary is that section of the Delaware River (and tidal portions of its tributaries) between the head of Delaware Bay and the head of the tide in Trenton, New Jersey-about eightyfive miles. DEL. River BASIN COMM'N, U.S. EPA, TOTAL MAXIMUM DAILY LOADS FOR POLYCHLORINATED BIPHENYLS (PCBS) FOR ZONES 2-5 OF THE TIDAL DELAWARE RIVER i-ii (2003) [hereinafter DELAWARE RIVER TMDL]. It is designated as fishable waters and listed as impaired on the $\S 303$ (d) lists of Delaware, New Jersey, and Pennsylvania, based on elevated levels of PCBs in fish tissue. $I d$. at ii. 
multiple parties on May 31, 2005, and withdrawn in October 2005. ${ }^{109}$ The fifth and final controversy followed the EPA's issuance of a complex TMDL in October 2003, for segments of the Wissahickon Creek impacted by nutrients and silt in lower Montgomery County and the highly urbanized northwestern Philadelphia County. ${ }^{110}$ The City of Philadelphia appealed the TMDL in October 2005, but withdrew its appeal in May 2006. ${ }^{111}$ For purposes of comparison, we also looked at the District of Columbia litigation between the EPA and Friends of the Earth over the validity of the Anacostia River TMDL for nutrients and silt in various regions, including Montgomery County, Maryland. ${ }^{112} \mathrm{We}$ focused on the documents in the federal lawsuit, a much more formal setting for technical and scientific arguments, to see whether idealized arguments played a role. ${ }^{113}$

\section{B. Categories of Arguments}

Our first category of arguments claiming too much uncertainty, or too conservative a margin of safety, expanded to include idealized arguments claiming there was not enough data, too many assumptions, too little reliability, and other shortcomings identified as flaws without indicating what the threshold might be for overcoming the flaw. That is, as there will always be uncertainties, incomplete data, assumptions, and some conservatism regarding margins of safety, we categorized as idealized those arguments implying that any shortcomings rendered the TMDL unscientific. The second category was less complex and distinguished the idealized arguments that did not consider the effect of the claimed flaw from those that considered the effect but did not consider the magnitude of the effect. The third category included arguments that were idealized because no alternative method or better

109. Docket, Delaware County Reg'l Water Quality Control Auth. v. PaDEP, No. 2005-115-K, http://ehb.courtapps.com/public/document_shower_pub.php?docket_no=2005115 (last visited Sept. $27,2008)$.

110. The PaDEP listed Wissahickon Creek as designated for trout stocking and impaired due to nutrients, silt, low dissolved oxygen, chlorine, flow variability, oil, grease, and pathogens. See U.S. EPA, NutRiENT AND SiLTATION TMDL DEVELOPMENT FOR WisSAHICKON CREEK, PENNSYLVANIA (2003) [hereinafter WISSAHICKON CREEK TMDL].

111. See Notice of Appeal, City of Philadelphia v. PaDEP, No. 2005-308-M6 (Pa. Envtl. Hearing Bd. Oct. 25, 2005). When the City of Philadelphia received a new NPDES permit in September 2005, it appealed the permit to the Board, but withdrew its appeal on May 15, 2006. See id. The City, it appears, was essentially challenging its NPDES permit, and its challenge to the TMDL (established by the EPA) was primarily to preserve arguments for a federal court appeal if deemed necessary.

112. Friends of the Earth, Inc. v. EPA, 446 F.3d 140, 142-43 (D.C. Cir. 2006).

113. See supra notes $92-94$ and accompanying text. 
process was offered. These three categories are reflected in Table $1,{ }^{114}$ which summarizes the arguments discussed in more detail in the following narrative.

\section{Claims of Threshold Failures Lacking Thresholds}

\section{a. Initial Examples}

Four of the municipal dischargers affected by the Skippack Creek TMDL (an effort to reduce excessive algae by reductions of nutrients) submitted comments on the draft TMDL, several of which illustrate, respectively, an aspect of the first form of idealized argument. The Upper Gwynedd-Towamencin Municipal Authority argued that the model calibrations were poor and "of considerable concern, because it suggests that predictions with the model have such a high level of uncertainty that they cannot be relied upon to demonstrate that the TMDL objectives will be achieved." 115 In response to such ambiguities - a "high level of uncertainty," unreliable predictions, poor calibrations - the EPA simply stated that "the calibration and validation are good. There was a margin of safety used to account for uncertainty." 116 Although the EPA has been criticized for arbitrary selection of margins of safety without thoroughly analyzing the uncertainty of its models (which could minimize forecast error), ${ }^{117}$ such that objections to TMDL uncertainty can be justified, the above comment suggests no standard.

Similarly, criticism that the supporting data are insufficient, without indicating a level of sufficiency, was categorized as an implicit idealization. For example, the Borough of Lansdale commented that the original $\S 303(d)$ listings "were based on inadequate information ... and that the data should be enhanced with a more rigorous scientific analysis...."118 On this point, which raises doubts about whether Skippack Creek is impaired by algae, the EPA curtly responded that not only does the data confirm pollutant sources, but that visual inspection reveals the presence of excessive algae in the waters- "thick green

\footnotetext{
114. See infra Table 1.

115. SKIPPACK COMMENTS/ReSPONSES, supra note 57, at 6, cmt. 02-01.

116. Id. at 3, cmt. 01-05, response 01-05.

117. See NAT'L RESEARCH COUNCIL, supra note 11, at 10 (stating the "EPA should end the practice of arbitrary selection of the margin of safety and instead require uncertainty analysis as the basis for margin of safety determination").

118. SKIPPACK COMMENTS/RESPONSES, supra note 57, at 33, cmt. 07-02.
} 
floating mats" of it. ${ }^{119}$ Another criticism, by the Lower Salford Township, questioned whether conducting limited in-stream water sampling and algal growth assessment at a dozen sites "on only two days within a thirty day time period" was sufficient. ${ }^{120}$ As no higher standard was proposed, the EPA simply responded that this "data collection program was carefully designed," and the "data [were] used to calibrate and validate a water quality model ... [that was] used to simulate the conditions in the stream under critical conditions." 121

Finally, the Borough of Souderton demanded the EPA conclusively show "that water quality standards will be attained," 122 which we classified as an idealized demand for certainty. The EPA, however, did not view the comment as an unreasonable uncertainty claim, but rather responded that its "analysis does indeed show that the goal will be met." 123 This may signal a different standard for "conclusively showing" something, but in any event indicates that the EPA viewed the comment as a reasonable argument. By contrast, in response to a comment by the Borough of Lansdale that the "TMDL does not show that the water quality standards will be attained by its implementation," 124 the EPA stated that the TMDL "was based in sound science and existing ... sitespecific data and information." 125 This response seems to recognize an unreasonable demand for certainty and proof, which accords with our assessment that the challenge was idealized. Significantly, the issue in both of these claims for more certainty (regarding the effectiveness of the TMDL) is whether nonpoint sources are the major cause of algae growth, which is a justifiable concern. Therefore, the argument by the Borough of Souderton, in another comment, that its interpretation of the data indicates that point source controls will not correct the algae problem, ${ }^{126}$ is a reasonable scientific argument-it can be framed as a controversy

\footnotetext{
119. Id., response 07-02.

120. Id. at 28 , cmt. $06-08$.

121. Id., response 06-08.

122. Id. at 24, cmt. 05-15. The comment identifies segments of Skippack Creek that exceed the algae level even though there is no point source in those segments, states that the impact of nonpoint sources has been ignored, and paraphrases a PaDEP representative who acknowledged the uncertain benefits of reducing phosphorus levels. Id.

123. Id., response $05-15$.

124. Id. at 39, cmt. 07-14. The comment suggested the algae problem may lie with nonpoint sources, and that the EPA "has not demonstrated that reductions in phosphorus discharges from point sources ... will attain the goal." Id.

125. Id., response 07-14.

126. Id. at 16 , cmt. 05-03.
} 
over interpretation of the data rather than an idealized demand for certainty. In its response, the EPA confirmed its own interpretation:

[T] he main cause of the high levels of algal growth is caused by the large amounts of nutrients, particularly phosphorus, that is being discharged by the wastewater treatment facilities.... [C]ontribution of phosphorus from nonpoint sources is insignificant as compared to the point sources at low flow conditions. ${ }^{12}$

The EPA took the comment as a serious scientific challenge and then declared it to be wrong.

Because of our interest in identifying the form or structure of idealized arguments, we neither considered idealized arguments to be "wrong" nor even attempted to judge the scientific correctness or validity of arguments in our study. For example, the Borough of Souderton saw no documented "correlation between in-stream phosphorus concentration and algae growth," and pointed out that the EPA report conceded the data does "not appear to directly link specific water quality data ... with the excessive algal growth observed." ${ }^{\prime 28}$ In our framework, claims of no correlation are not idealized, but as the EPA explained in its response, numerous studies establish that link, and also demonstrate:

[T] he nutrient-periphyton chlorophyll relationship reaches a plateau at high nutrient concentrations, because the periphyton becomes nutrientsaturated. [Skippack Creek] nutrient concentrations and periphyton chlorophyll levels are very high and correspond with this plateau.... [s]o that we would not expect to see a strong correlation between their biomass and water quality parameters.

That is, at the saturation point, any addition of nutrients will not cause more algae - the EPA rejects the stakeholder's argument as misguided. Similarly, when the Borough of Souderton argued that its phosphorus discharges are well upstream of the substantial algae blooms, and therefore appear unrelated to the problem, the EPA explained that the impact of the Souderton wastewater facility can be far afield, "almost to the mouth of the Skippack even with all other point sources at zero."130 Moreover, "circumstances such as toxic metals in an effluent may

127. Id., response 05-03.

128. Id. at 15, cmt. 05-02. The Borough also argued that the apparent lack of correlation (between algal biomass and nutrient levels) was supported by eleven of forty-six papers reviewed, which is a significant variation, leading the Borough to conclude that the TMDL lacks a "sound basis." Id.

129. Id., response 05-02.

130. Id. at 17 , response $05-04$. 
[inhibit] algal growth ... near the discharge due to toxicity." ${ }^{\prime 31}$ The Borough's argument may be wrong, but it was a reasonable scientific question about the data and not an idealization. Indeed, another argument by the Borough of Souderton appears to reflect a valid concern. When it questioned the EPA's target criterion based on only one study and cited other studies with a higher target criterion, the EPA cited additional research for its position. ${ }^{132}$ But the argument engendered a genuine controversy. ${ }^{133}$ On the other hand, the Borough of Souderton's general claim in its appeal that the TMDL "lacks a proper scientific basis," 134 without more, is an idealized argument because the threshold of propriety remains unspecified.

The foregoing summation illustrates four different aspects of implied claims of uncertainty that correspond to four types or forms of arguments: (1) implied claims that there is too much uncertainty, (2) claims that the amount of data is inadequate and therefore the results are too uncertain, (3) claims that the attainability of the TMDL goals is not sufficiently demonstrated (i.e., too little confidence in the TMDL), and (4) general claims that the TMDL lacks a scientific basis. Each type of argument is potentially reasonable and justifiable, but we categorized arguments that offered no threshold for (1) acceptable uncertainty, (2) adequate data, (3) confidence levels, or (4) scientific validity, as idealized.

It should be mentioned that while this study was focused on the TMDL establishment stage, not the implementation stage, stakeholder comments often raised implementation concerns about whether the TMDL goals can be achieved, and sometimes conflated two different issues: (1) whether water quality standards will be met by the TMDL, regardless of source of pollution (i.e., the TMDL is inadequate); and (2) whether the TMDL can be achieved by adjusting a point source discharger's permit (i.e., an adequate TMDL cannot be fully implemented because of nonpoint source problems). While the former involves the sort of scientific arguments evaluated in this study, the latter is more an issue of regulatory policy and politics (e.g., is PaDEP actively regulating nonpoint sources?). Challenges related to the latter are not

131. Id.

132. See id. at 18, cmt. 05-06; response 05-06. Specifically, the EPA's target criterion (or "impairment trigger") of $100 \mathrm{mg} / \mathrm{m}^{2}$ for the in-stream periphyton biomass (measured by chlorophyll a) value, was considered too low by the New Jersey Department of Environmental Protection (NJDEP). The NJDEP drew on research indicating that this value could be as high as $200 \mathrm{mg} / \mathrm{m}^{2}$ before any initial impacts are observed. See id.

133. See supra note 132.

134. Notice of Appeal, Borough of Souderton, supra note 102, $₫ 20$. 
challenges to the scientific quality of the TMDL, but when the two are conflated, the result is not so much an idealization of science as a legal idealization. Stakeholders may imply that implementation problems invalidate the TMDL, but questions about TMDL effectiveness in meeting water quality standards are independent from questions about how the TMDL program will be implemented.

\section{b. Additional Examples}

i. Too Much Uncertainty

Most of the complete and sophisticated arguments in opposition to the Skippack Creek TMDL are found not in the brief comments on the draft TMDL, but in the four scientific reports commissioned by stakeholders and filed with PaDEP just after the Borough of Souderton appealed the TMDL to the Environmental Hearing Board. ${ }^{135}$ For example, one consulting firm argued in its report that because numerous factors affect stream periphyton biomass, including light, grazing, hydrology, and nutrients, the evaluation of nutrient concentrations should be site-specific - developing data from sites outside the region "is inadequate ... in developing a target stream phosphorus concentration ... because the uncertainty in the regression equation is too great and unacceptable."136 The consultant's demand for "good data" and an "experienced analyst [who] can provide... quantitative insight"137 seems realistic, but is idealized insofar as we do not know how good the data must be, how experienced the analyst needs to be, what quantitative insight will be available, or how much uncertainty is acceptable. That consultant also criticized the subjectivity of Dr. Carrick's determination of nuisance level, ${ }^{138}$ suggesting a certain idealization of TMDL science as necessarily objective; a more realistic argument is the consultant's claim that there is no scientific consensus (a subjective factor) concerning the nuisance level that Dr. Carrick found in the scientific literature, but even that criticism is idealized insofar as the report does not address the question of what consensus exists. ${ }^{139}$ This consultant's report is particularly important for our study, because from one vantage it

\footnotetext{
135. See supra note 103 (citing the four scientific reports, three of which were reviewed for this study).

136. HYDROQUAL, INC., supra note 103, at 5.

137. Id. at 6 .

138. See id.

139. See id. at 2.
} 
represents a carefully constructed attack on the flaws and shortcomings of Dr. Carrick's report, and therefore appears to be a reasonable and justifiable argument in favor of sound data, scientific rigor, and consensus-building. ${ }^{140}$ On the other hand, because the arguments are almost wholly deconstructive-raising numerous objections without indicating what might be acceptable - the arguments imply that perfection is the goal. ${ }^{141}$ Indeed, the report also exemplifies the other three argument forms based on an uncertainty claim, namely the inadequacy of the data, the failure of the TMDL to achieve its goals, and the lack of a scientific basis. ${ }^{142}$ Moreover, the consultant's report serves as an example of our other two categories of idealization, namely challenges that fail to consider the effect (or its magnitude) of identified flaws, and challenges that do not offer alternative procedures or methodologies. ${ }^{143}$ In this sense, the consultant's arguments can be viewed as hyper-idealized, notwithstanding their foundation in valid scientific concerns.

Finally, in the controversy surrounding the Neshaminy Creek TMDL, which was withdrawn for the same reason the Skippack Creek TMDL was withdrawn, ${ }^{144}$ the Borough of Lansdale based one of its objections to the draft TMDL on a statement in the draft that "it is very difficult to ascertain if nutrient loadings are in fact a problem in the Neshaminy Creek Watershed."145 We classified this objection as idealized insofar as it implies that any uncertainty is enough to delay the TMDL. Interestingly, that statement was removed from the final TMDL, which confirmed the PaDEP's view that nutrients are indeed a problem in Neshaminy Creek.

140. For example, HydroQual highlights the importance of seasonal changes for nutrient concentration analyses, as well as the need for spatial averaging (stream width) and averaging over a specified length of stream. See id. at 3. The report is also attentive to the problematic aspects of modeling where the "empirical components ... weaken [a model's] predictive power," where there is little "testing against actual stream data," and where calibration is not based on site-specific data. Id. at 6 .

141. See id. at 6-7.

142. HydroQual ambiguously demands "good data," suggests that background phosphorus and the failure to restore tree canopy will render the TMDL ineffective, and argues that Dr. Carrick's target levels for chlorophyll $a$ are "arbitrary," "not based on scientific principles," and lack "scientific rigor." Id. at $1-4,6$.

143. HydroQual's concerns about seasonal changes, and the need for spatial and length-ofstream averaging, for example, raise doubts without identifying the effects of alternative analyses, even if such "averaging" represents an alternative methodology. See id. at 3.

144. See supra note 102 (detailing the relevant dates for the Skippack Creek TMDL and how Dr. Carrick's error resulted in the Skippack Creek TMDL withdrawal).

145. See Letter from Jacob Ziegler, Director of Utilities, Borough of Lansdale, to PaDEP (Nov. $14,2003)$, at 8 . 


\section{ii. Not Enough Data}

In the Wissahickon Creek TMDL controversy, one of the critical comments to the draft TMDL referred to the use of best management practices (BMPs) - the typical requirement imposed to address nonpoint source pollution - to achieve loading reduction goals: "[u]ntil enough scientifically valid data are generated to determine what needs to be done, the use of BMPs is a viable option that should be considered before imposing [an] unnecessary TMDL."146 This argument is idealized because it offers no definition of "enough scientifically valid data," and generally implies that the TMDL is insufficient, without offering a standard for sufficiency.

Likewise, in the Conestoga Headwater TMDL controversy, the Borough of New Morgan (joined by four developers) filed a notice of appeal with the Pennsylvania Environmental Hearing Board immediately after notice of the TMDL was published in the Pennsylvania Bulletin; ${ }^{147}$ objections included PaDEP's reliance on "old, inadequate data" to determine impairment, as well as "inadequate data" to develop the TMDL. ${ }^{148}$ Also, a developer that had joined the appeal, New Morgan Properties, amended its appeal a month later; its objections included the claim that PaDEP did not "provide an appropriate level of technical analysis supporting all TMDL elements," and that the TMDL is not based on "adequate and appropriate data, modeling[,] and analysis ...." "149 These arguments are idealized insofar as they do not suggest standards for adequate data or an appropriate level of analysis or modeling. However, as these are claims in an appeal, one would not expect a complete scientific argument; if the appeals had reached a hearing (they were withdrawn in November $2006^{150}$ ), the parties would have presented evidence to support these claims. By way of contrast, the

146. EPA, WISSAHICKON RESPONSIVENESS SUMMARY, 16, cmt. 34-13 (2003). The EPA responded that the TMDL, rather than being an alternative to BMPs, "can be used as a basis for determining the need for BMPs, determining the level of removal necessary from BMPs to meet water quality standards and the general location of where BMPs would be most effective." $I d$. at 16, response 34-13; 7, response 31-12.

147. 35 Pa. Bull. 13, 1936 (March 26, 2005). The notice directed readers to the PaDEP website, http:/www.dep.state.pa.us/watermanagement_apps/TMDL/ (last visited Sept. 26, 2008), for access to the TMDL document.

148. Notice of Appeal, Borough of New Morgan v. PaDEP, No. 2005-078-K ๆ 22(a) (Pa. Envtl. Hearing Bd. Apr. 25, 2005).

149. Amended Notice of Appeal, New Morgan Props., L.P. v. PaDEP, No. 2005-079-K \ 34(a), (c) (May 13, 2005).

150. Docket, New Morgan Props., L.P. v. PaDEP, No. 2005-079-K, http://ehb.courtapps.com /public/document_shower_pub.php?docket_no=2005078 (last visited Sept. 26, 2008). 
comments made to the EPA or PaDEP, and the technical reports consultants submitted on behalf of challengers when a draft TMDL has been published, are often relatively complete scientific arguments. For example, regarding the technical reports, one consultant made a claim that the Skippack Creek TMDL is invalid because the EPA used an inappropriate, nonstandard method to measure algae that over-predicted algae in the order of two to sixty times a valid prediction. ${ }^{151}$ This claim is not idealized. First, it does not simply state the uncertainty is too great, but rather implies that an accepted procedure, the standard method, establishes the standard for uncertainty. Second, the claim does not state that any error is unacceptable, but rather that the method used by the EPA was more erroneous than the standard method. Finally, the claim considers the effect of the error-overprediction-and specifies its significance.

Another example, this time from the Neshaminy Creek TMDL controversy, is the Borough of Lansdale's challenge, in comments to PaDEP, regarding the use of default or "textbook" data concerning stream conditions and characteristics in the computer model, and its suggested use of site-specific stream data; basing calibration of the model on data from only one water quality monitoring station is criticized, and obtaining data from each sub-basin is suggested. ${ }^{152}$ While these suggestions make the arguments stronger than an idealized argument, PaDEP viewed the argument as misguided, because its model did not use "default or textbook data," but rather actual data as to land use, soils, topography, and climate "to drive the model."153 Moreover, very few default values were employed and the techniques used to estimate various parameter values were based on well-established, standard approaches. ${ }^{154}$ PaDEP continued: "while there are more complex methodologies available and additional stream measurements [that] could have been made, we can conclude that the parameter values used in the modeling reflect the true condition based upon the accuracy of the simulated hydraulics and pollutant loads."155 This response highlights the manner in which PaDEP considered the Borough's

151. See infra note 254 and accompanying text.

152. COMMENTS AND ResPonses (NEW) app. H, in NESHAMINY CREEK TMDL, supra note 107, at 7 (comment section) [hereinafter NESHAMINY CREEK COMMENTS/RESPONSES]. Because the argument concerning inadequate data offers some standards for review, it is not idealized. However, we later classified this same argument as idealized because it does not specify the likely effect of better data on the TMDL. See infra note 183 and accompanying text.

153. NESHAMINY CREEK COMMENTS/RESPONSES, supra note 152, at 7 (PaDEP response).

154. Id.

155. Id. at 9 . 
argument, even with its additional details, an idealized demand for more accurate data. In short, any approach can be attacked for its assumptions, estimates, simulations, modeling, and therefore incomplete data, but those features do not in themselves render the TMDL unscientific.

\section{iii. TMDL Goals Will Not Be Achieved}

Another form of the idealized demand for certainty is the argument that the TMDL will not be effective. For example, in the Skippack Creek TMDL controversy, the Borough of Lansdale stated that the "TMDL does not show water quality standards will be attained by its implementation" because the impairment problem may lie with nonpoint sources - the EPA "has not demonstrated that reductions in phosphorus discharges from point sources... will attain the goal." 156 The EPA, viewing that argument as demanding too much, responded that the TMDL "was based in sound science and existing state procedures, policy and site-specific data and information."157 Notably, the same strategy was employed by an environmentalist law firm, the Mid-Atlantic Environmental Law Center, which questioned the EPA's assumption that if "the ambient water quality target is met under critical conditions and the most stringent scenario," then it should be met under all other conditions. ${ }^{158}$ The EPA viewed the demand to eliminate such assumptions as unreasonable or idealized because "it stands to reason" that a target met under critical conditions will be met in less critical conditions. $^{159}$

In the Conestoga Headwater TMDL controversy, numerous comments were submitted by a developer of "smart growth" towns, including the charge that PaDEP "has not provided reasonable assurances that the load reductions required by the TMDL can be achieved." 160

156. SKIPPACK COMMENTS/RESPONSES, supra note 57, at 39, cmt. 07-14.

157. Id., response 07-14.

158. Id. at 12, cmt. 03-12. The Center is a not-for-profit law firm serving public interest organizations. See Mid-Atlantic Environmental Law Center, http://www.maelc.org (last visited Sept. 26, 2008).

159. Id. at 12 , response $03-12$. "Critical condition" is a worst case scenario, which in this case is low flow because dilution is lowest and concentration is highest.

160. Comment \& Response Document for the Conestoga Headwaters TMDL app. G, in CONESTOGa HeAdwaters TMDL, supra note 104, at 35, PaDEP response [hereinafter Conestoga Comments/Responses]. When the developer later filed an appeal to the Pennsylvania Environmental Hearing Board, it repeated the argument that the TMDL was deficient due to lack of "reasonable assurances that the nonpoint source load reductions ... can be achieved." See Notice of Appeal, Borough of New Morgan, supra note 148, 922. 
PaDEP's response indicates that the agency views such an argument as excessive:

The TMDL does not prescribe the exact BMPs [for non-point sources] or activities that need to be put in place that will result in meeting the allowable loading... determined in the analysis. Subsequent remediation planning and implementation need to take place for the waterbody to recover, and subsequently additional biological monitoring will determine if the waterbody is attaining designated uses and can be removed from the list of impaired waters. ${ }^{16}$

The subtext is clearly a frustrated acknowledgement of remediation uncertainty in the process, and efforts to eliminate uncertainty are viewed as idealizations. Moreover, the issue of implementation, described in the above response, is different from the issue of whether the TMDL is scientifically sound.

\section{iv. Lack of a Scientific Basis}

The final form of arguments that imply uncertainty in the process is too great include general claims that the TMDL is not "scientifically defensible" (or does not reflect "current science") ${ }^{162}$ or "is contrary to accepted engineering practice," $" 163$ as well as more specific claims that, for example, the target levels for chlorophyll $a$ were "arbitrary and not based on accepted scientific principles."164 Such arguments appear idealized because they are based on an unspecified scientific standard. The EPA or PaDEP typically responded to this by claiming "[t]he TMDL is based on scientifically valid data and procedures"; therefore, "[t]he TMDL stands as is and will not be withdrawn or delayed."165

All three appeals in the Neshaminy Creek TMDL controversy claimed that PaDEP's mathematical modeling results were inaccurate. ${ }^{166}$ While one would not expect further argument in an appeal document, the claim does highlight the fact that some level of inaccuracy in modeling is

\footnotetext{
161. Conestoga Comments/Responses, supra note 160, at 35, PaDEP response.

162. WISSAHICKON RESPONSIVENESS SUMMARY, supra note 146, at 19, cmt. 35-01.

163. Id. at 26, cmt. 35-17.

164. HYDROQUAL, INC., supra note 103, at 1.

165. See WiSSAHICKON RESPONSIVENESS SUMmARY, supra note 146, at 19, response 35-01.

166. See Notice of Appeal, Chalfont-New Britain Twp. Joint Sewage Auth., No. 2004-112-K, ๆ 50(h) (Pa. Envtl. Hearing Bd. May 12, 2004); Notice of Appeal, Borough of Lansdale v. PaDEP, No. 2004-045-K, | 33(m) (Pa. Envtl. Hearing Bd. Feb. 26, 2004); Notice of Appeal, Hatfield Twp. Mun. Auth. v. PaDEP, No. 2004-046-K, ๆ 53(h) (Pa. Envtl. Hearing Bd. Apr. 18, 2007). These appeals were consolidated as Hatfield Twp. Mun. Auth. v. PaDEP, No. 2004-046-MG (Pa. Envtl. Hearing Bd.).
} 
inevitable. For example, in the Wissahickon Creek TMDL controversy, one commenter complained that "basing any TMDL on such limited data [e.g., a single sample measurement only "marginally below the minimum standard'] is scientifically unsound, unrealistic, and not reflective of real world conditions." 167 The EPA responded that the commenter perhaps misunderstood, and therefore idealized, water quality regulations:

[T] he TMDL was based on, not specifically existing conditions, but on design conditions, which represent higher effluent flows and hence loadings of pollutants. The existing stream concentrations may not represent those design conditions.... [The] EPA believes that this TMDL is based on sound science, is realistic to design conditions[,] and reflects the actions and reactions within the Wissahickon Creek and its tributaries. 168

The inevitability of uncertainty-that is, when every existing stream concentration is not reflected in model-based regulation-does not signal a fundamental flaw in the TMDL. Indeed, the frequent claim in commissioned scientific reports that nuisance levels for some chemicals are "arbitrary," 169 which reflects the legal standard for invalid administrative regulations, tends to eclipse the more minimal "arbitrariness" of round numbers such as " $200 \mathrm{mg} / \mathrm{m}^{2}$ " or the range of " $100-150 \mathrm{mg} / \mathrm{m}^{2}$." Moreover, there is certainly a potential false perception of accuracy in setting "daily loads," which appear to be precisely designated fractions of pounds but which are in fact not so neatly measurable. Some level of inaccuracy and "arbitrariness" is therefore ubiquitous in the TMDL process and arguments based on the presence of uncertainty alone tend to demand perfection and thereby become idealized.

2. Arguments That Do Not Consider the Effect of an Alleged Flaw or its Magnitude

\section{a. Effect}

We considered some of the scientific challenges in the TMDL process to be implicitly idealized because various shortcomings with respect to data or methodology were raised without considering, addressing, or speculating on the effect of those shortcomings on the

167. WISSAHICKON RESPONSIVENESS SUMMARY, supra note 146, at 15, cmt. 34-12.

168. See id. at 15, response 34-12.

169. See F.X. Browne, InC., supra note 103, at 16; HydroQuAL, InC., supra note 103, at 2. 
TMDL. For example, in the notice of appeal to the Pennsylvania Environmental Hearing Board, filed by two municipal authorities in the Skippack Creek TMDL controversy, the dischargers claimed the methodology used to develop the TMDL is fundamentally flawed - the data were unreliable: nonpoint source pollution, local conditions, and the effect of sunlight were not considered. ${ }^{170}$ However, there was no suggestion these deficiencies would change the TMDL or increase allowable loadings. While one could argue an appeal document is not the place to discuss effects, even the expert hired by one of the municipal authorities did not address in his company's report the effect that a demand for local, site-specific data might have on the TMDL. ${ }^{171}$ Likewise, another expert commissioned to evaluate the science behind the Skippack Creek TMDL raised legitimate concerns about the effect of seasonal changes and the need for spatial averaging for stream analyses, but he did not in that criticism identify the effect (on the TMDL) if different data or methodologies were used. ${ }^{172}$ A third expert recommended further research because the report relied upon by the EPA was "not scientifically defensible," but he did not address the effect of using more empirical literature on the TMDL. ${ }^{173}$

In the Wissahickon TMDL controversy, one of the comments criticized the EPA for assuming "unrealistic flow scenarios" (the EPA model was based on low-flow conditions), but did not consider the effect of a more realistic model. ${ }^{174}$ The importance of considering the effect of more data or more realistic models is highlighted, quite dramatically, in the EPA's response to the foregoing criticism - the EPA created an appendix representing a "more detailed analysis of the [available] seasonal data," which "actually resulted in more stringent effluent

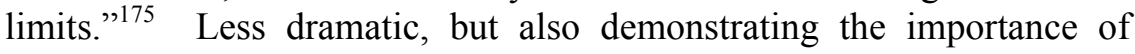
considering the effect when a flaw is identified, is the EPA's response to a very reasonable comment in the Wissahickon controversy criticizing the EPA's assumption that the siltation load of a reference watershed represents the maximum allowable load above which the watershed

170. See Notice of Appeal, Lower Salford Twp. Auth., supra note 102, Ф甲 50-55.

171. F.X. BRownE, INC., supra note 103, at 8. The F.X. Brown report was commissioned by Borough of Souderton \& Upper Gwynedd Twp. Telephone Interview with Frank X. Browne, President, F.X. Browne, Inc. (Sept. 27, 2007).

172. HYDROQUAL, INC., supra note 103, at 3.

173. CARROLl ENG'G CORP., supra note 103, at 5-6 (criticizing Dr. Carrick, see supra note 101, for relying on empirical research focused on lakes, not streams).

174. WISSAHICKON RESPONSIVENESS SUMMARY, supra note 146, at 9, cmt. 31-17.

175. Id. at 9, response 31-17 (referring to Appendix D, WISSAHICKON CREEK TMDL, supra note 110 , at D-11). 
would be impaired, even though there is no evidence that additional loading would be unacceptable. ${ }^{176}$ For the EPA, the "reference watershed approach provides an estimate of the TMDL for the impaired watershed, but certainly is not assumed to be exact. [The] reference watershed may understate [or overstate] the maximum load possible .... To provide additional assurance ... an explicit margin of safety was also used." 177 In other words, the reference watershed approach (a commonly used and scientific method) is not based on proof that the reference stream is unimpaired. So, it is clearly not the best evidence potentially available. The TMDL process therefore exemplifies the limitations on data (and resources to generate data) prior to regulation, but the margin of safety is supposed to ensure that the TMDL effect of more accurate data would be minimal. Thus, when a discharger pointed out that the Wissahickon TMDL did not account for tributaries such as Sandy Runsuch that "there is no way of evaluating whether the model reasonably predicts conditions in Sandy Run"178 - the EPA responded that observed data on Sandy Run was consistent with simulated results, but "no mathematical model is developed to mimic all details of a real system (which is virtually impossible). Considering all limitations of mathematical formulations, numerical solutions, and data sparseness against system complexity, a model can only be expected to represent the general behavior of the prototype system." ${ }^{179}$ The EPA not only considered the argument to be an idealized demand for more data, but also suggested that the effect of any errors was minimal: "the model has been validated[,] . . . showed reasonable representation of the [dissolved oxygen] profile, ... [and] was determined a sufficient representation ... of the general magnitude" of relevant nutrients. ${ }^{180}$

In the Conestoga Headwater TMDL controversy, a developer's comments (1) that the data collection techniques (sampling locations and dates) were insufficient to determine current phosphorus loadings and needed reductions, and (2) that the reference watershed approach is "inadequate because of the myriad of differences between watersheds," $" 181$ are idealized arguments insofar as there is no consideration of the effects of more data on the TMDL, or what level of

\footnotetext{
176. WISSAHICKON RESPONSIVENESS SUMMARY, supra note 146, at 21, cmt. 35-06.

177. Id., response 35-06.

178. Id. at 24, cmt. 35-12.

179. Id., response 35-12.

180. Id. at 25 , response $35-13$.

181. Conestoga Comments/Responses, supra note 160 , at $32-35$. Notwithstanding our categorization of these arguments as idealized, the developer, on the basis of these arguments, received some favorable revisions to the TMDL.
} 
differences would be appropriate. Likewise, the Borough of New Morgan, in its appeal to the Conestoga Headwaters TMDL, objected to "reliance on old, inadequate data" to determine impairment, inadequate data to develop the TMDL, and lack of site-specific evaluations of phosphorus levels, all without considering the effect of new or more data on the TMDL. ${ }^{182}$

In the Neshaminy Creek TMDL controversy, the Borough of Lansdale's comments on the draft TMDL also included an argument that without site-specific stream data from each sub-basin, the TMDL is deficient, but there was no indication how the TMDL might change if additional data was used. ${ }^{183}$ Of course, the commenter might reply that such change is implied by the argument for more data. Indeed, the Borough of Lansdale's comment that PaDEP's model should be based on algal growth, the alleged nuisance, rather than on phosphorus loading, suggests the effect on the TMDL would be substantial. ${ }^{184}$ PaDEP responded that nuisance algal growth is caused by excess phosphorus, and that in any event actual stream assessments revealed excessive algae; in short, by focusing on algal growth instead of phosphorus, the model would still be an approximation of actual conditions. ${ }^{185}$

Finally, with respect to the Delaware PCB TMDL controversy, given that some level of error, uncertainty, and inaccuracy is inevitable in the TMDL process, the failure to discuss the effect of some of these flaws on the TMDL transforms otherwise reasonable concerns into an idealized demand for accuracy without regard to whether the result of EPA's analysis would change. For example, the comment by HydroQual that the Delaware PCB TMDL did not consider all sources of PCB contamination does not address how that error would affect the EPA's load levels. ${ }^{186}$ Interestingly, however, HydroQual then accused the EPA of failing to discuss the "effect of [its own] error" when the EPA conceded that "the full inventory of Contaminated Site loadings from

182. Notice of Appeal, Borough of New Morgan, supra note 148, $\uparrow$ 22. In its amended appeal, the Borough of New Morgan also noted a failure "to consider spatial and temporal variations in loading capacity," but did so without addressing how such considerations would affect the TMDL. Amended Notice of Appeal, Borough of New Morgan v. PaDEP, No. 2005-078-K, I 29(k) (Pa. Envtl. Hearing Bd. May 13, 2005).

183. NeShAMINY CREEK COMMENTS/ReSPONSES, supra note 152, at 7.

184. Id. at 9 .

185. Id., PaDEP response. "Even a model that attempts to compute algal cell growth can not answer the question of 'how much is too much?' That question can only be answered by actual stream assessments." Id.

186. HydroQual, InC., Comments on the DRBC PCB TMDL Models, in Comments of THE Delaware ESTUARY TMDL COALITION ON THE PCB TMDLS FOR THE DELAWARE ESTUARY app. C, at C-1 (2003) [hereinafter DELAWARE COMMENTS]. 
New Jersey were not included due to time constraints." "187 Nevertheless, by identifying its own shortcuts and limitations, the EPA is not failing to consider the effect of those shortcomings, but rather concluding that, given a margin of safety, the effect of those shortcomings is minimal.

\section{b. Magnitude of the Effect}

Even when dischargers challenging a TMDL speculate as to the effect of an identified error, the magnitude of the effect is often not addressed. For example, in the Neshaminy Creek TMDL controversy, five municipal wastewater authorities filed a notice of appeal to the Pennsylvania Environmental Hearing Board. The appeal included an argument that while seven reservoirs discharge into Neshaminy Creek, the TMDL model only took four into account, which had the effect of over-estimating the amount of phosphorus coming from wastewater. ${ }^{188}$ However, there is no mention of whether the effect would be significant. The Delaware PCB TMDL controversy included another example of this failure, found in a comment by HydroQual criticizing the EPA for assuming in its model that fish and water concentrations are at a constant ratio, rather than using a fish bioaccumulation model. An effect of this shortcoming was identified - namely that fish tissue PCB concentrations may not decrease as predicted in the model ${ }^{189}$ - but that over-prediction could be small or negligible. The implicit idealization in such arguments is that the error becomes the focus of attention, as if any error invalidates the TMDL, rather than focusing on the result of the EPA model- the probabilistic accuracy and potential effectiveness of the prescribed load levels. Without saying as much, the EPA considers such arguments to be idealized, as indicated by references in its responses to comments to margins of safety, the limitations of and lack of precision in mathematical models, and the inevitable uncertainty in its analyses.

Arguments calling for more data, especially site-specific evaluations that take local factors (e.g., light, temperature, current substrate type, scouring effect of floods, or grazing) ${ }^{190}$ into account, appear reasonable. But, without addressing the effect of additional data and its magnitude, such arguments set idealized standards for regulating science. Indeed,

\footnotetext{
187. Id. at $\mathrm{C}-15$.

188. Notice of Appeal, Hatfield Twp. Mun. Auth., supra note 166, ๆ 53.

189. DelaWARE COMMENTS, supra note 186 , at C-12.

190. F.X. BRownE, INC., supra note 103, at 2; see also Conestoga Comments/Responses, supra note 160 , at 33 ("Extensive site-specific evaluations and analysis were required.... No such analysis appears to have been done ....").
} 
when the Borough of Lansdale, in the Neshaminy Creek TMDL controversy, pointed out (without discussing effect or magnitude) the "significant omission" of data for dissolved oxygen ranges (which are important to determine phosphorus uptake by fixed aquatic life), PaDEP responded that such "lack of data does not indicate a lack of support for the TMDL," which "was established to lower in-stream phosphorus concentrations and decrease attached algal growth." reached, then additional data on dissolved oxygen is not necessary except to serve an idealized conception of scientific certitude.

\section{Criticism Without Offering Alternatives}

Our last category of idealized arguments in the TMDL process captures those claims of analytical flaws that do not suggest an alternative analysis. For example, in the Skippack Creek TMDL controversy, a comment by a municipal authority on the draft TMDL that simply challenges the calibration of the model for the nitrogen and phosphorus series as "poor" and reflecting "a high level of uncertainty," without specifying improvements, leaves the EPA to respond, "[We] believe[] that the calibration and validation are good."192 Perhaps one cannot expect dischargers to suggest alternative analyses in a brief comment, but in the scientific reports commissioned to challenge the Skippack Creek TMDL, we also found examples of dismissive statements, claiming that the report on which the EPA relied is "scientifically incorrect," 193 without offering an alternative.

In the Wissahickon Creek TMDL controversy, one commenter simply stated that the TMDL "document is seriously flawed and should be withdrawn pending completion of a scientifically defensible TMDL and amendment of the water quality criteria to reflect current science and the actual time frames necessary to protect the existing and designated uses." 194 Without more, the EPA liturgically responded that "the TMDL is based on scientifically valid data and procedures," 195 as no alternative is suggested. Finally, in the Conestoga Headwater TMDL controversy, a developer's complaint that the sampling location and dates were insufficient, without more, leads to a PaDEP reply that the impairments

\footnotetext{
191. NeShAMINY CREEK COMMENTS/RESPONSES, supra note 152, at 6.

192. SKIPPACK COMMENTS/RESPONSES, supra note 57, at 3, cmt. 01-05.

193. See F.X. BROWNE, INC., supra note 103, at 20.

194. WISSAHICKON RESPONSIVENESS SUMMARY, supra note 146, at 19, cmt. 35-01.

195. Id. at 19 , response $35-01$.
} 
addressed in the TMDL have been confirmed. ${ }^{196}$ If no better procedure or method is offered by dischargers challenging the TMDL, then their objections are reduced to an idealized claim that good science is based on comprehensive data collection.

\section{Summary of Arguments}

Table 1 provides a summary of the above narrative, and includes an abbreviated statement of each of the forty arguments identified above as idealized:

Table 1: Typology of Idealized Arguments

\section{Arguments Involving Claims of Threshold Failure}

A. Too Much Uncertainty

- Model calibrations poor, suggesting a high level of uncertainty ${ }^{197}$

- Demand for "good data" from "experienced analyst" who can provide "quantitative insight",198

- No scientific consensus on the nuisance level used in the TMDL 199

- Whether nutrient loadings are in fact a problem is difficult to ascertain ${ }^{200}$

- Uncertainty in regression equation is too great because data from sites outside the region is inadequate ${ }^{201}$

- Reference watershed is not representative of subject watershed ${ }^{202}$

B. Not Enough Data

- Original listing as impaired was based on inadequate information ${ }^{203}$

- In-stream sampling at only a dozen sites on only two days is insufficient ${ }^{204}$

196. Conestoga Comments/Responses, supra note 160, at 32.

197. See supra note 115 and accompanying text.

198. See supra note 137 and accompanying text

199. See supra note 139 and accompanying text.

200. See supra note 145 and accompanying text.

201. See supra note 136 and accompanying text.

202. See supra note 176 and accompanying text.

203. See supra note 118 and accompanying text.

204. See supra note 120 and accompanying text. 
Table 1 (continued)

- Not enough "scientifically valid data" has been "generated"205

- Reliance on old, inadequate data ${ }^{206}$

- Inappropriate level of technical analysis ${ }^{207}$

- Calibration based on only one water quality monitoring station ${ }^{208}$

C. TMDL Goals May Not Be Achieved

- EPA cannot conclusively show that water quality standards will be achieved ${ }^{209}$

- TMDL does not show water quality standards will be achieved by implementation ${ }^{210}$

- EPA does not show that water quality target will be met under all conditions ${ }^{211}$

- PaDEP "has not provided reasonable assurances" that TMDL load restrictions can be achieved $^{212}$

\section{Lack of a Scientific Basis}

- TMDL "lacks a proper scientific basis"" 13

- TMDL is not "scientifically defensible" and does not reflect "current science"214

- TMDL analysis "is contrary to accepted engineering practice"215

- Target levels were "arbitrary and not based on accepted scientific principles"216

- Mathematical modeling results are inaccurate ${ }^{217}$

- Basing TMDL on limited data is scientifically unsound, unreliable, and unrealistic ${ }^{218}$

205. See supra note 146 and accompanying text.

206. See supra note 148 and accompanying text.

207. See supra note 149 and accompanying text.

208. See supra note 152 and accompanying text.

209. See supra note 122 and accompanying text.

210. See supra note 156 and accompanying text.

211. See supra note 158 and accompanying text.

212. See supra note 160 and accompanying text.

213. See supra note 134 and accompanying text.

214. See supra note 162 and accompanying text.

215. See supra note 163 and accompanying text.

216. See supra note 164 and accompanying text.

217. See supra note 166 and accompanying text.

218. See supra note 167 and accompanying text. 
Table 1 (continued)

\section{Failure to Consider Effect or Magnitude}

A. Effect

- Failure to consider nonpoint source pollution, local conditions, and effect of sunlight ${ }^{219}$

- Failure to use spatial averaging for stream analysis, and failure to consider effect of seasonal change ${ }^{220}$

- Further research needed (because of use of lake, not stream, data) ${ }^{221}$

- Failure to use local, site-specific data ${ }^{222}$

- Unrealistic flow scenarios were assumed ${ }^{223}$

- Failure to account for tributaries to $\mathrm{creek}^{224}$

- Insufficient data collection techniques and use of reference watershed inadequate ${ }^{225}$

- Reliance on inadequate data to develop TMDL 226

- TMDL is deficient without site-specific stream data from each sub-basin ${ }^{227}$

- Failure to consider all sources of PCB contamination ${ }^{228}$

B. Magnitude

- Only four of seven discharging reservoirs taken into account ${ }^{229}$

- Rather than using fish bioaccumulation model, EPA assumed fish and water concentration are at constant ratio 230

- Failure to take local factors (e.g., light, temperature) into account ${ }^{231}$

- Significant omission of data for dissolved oxygen ranges ${ }^{232}$

219. See supra note 170 and accompanying text.

220. See supra note 172 and accompanying text.

221. See supra note 173 and accompanying text.

222. See supra note 171 and accompanying text.

223. See supra note 174 and accompanying text.

224. See supra note 178 and accompanying text.

225. See supra note 181 and accompanying text.

226. See supra note 182 and accompanying text.

227. See supra note 183 and accompanying text.

228. See supra note 186 and accompanying text.

229. See supra note 188 and accompanying text.

230. See supra note 189 and accompanying text.

231. See supra note 190 and accompanying text.

232. See supra note 191 and accompanying text. 


\begin{tabular}{l} 
3. Criticism Without Offering an Alternative \\
\hline - Calibration of the model is poor and causes high level of uncertainty ${ }^{233}$ \\
- Report on which EPA relied is "scientifically incorrect"234 \\
- TMDL document is seriously flawed and is not scientifically current or defensible ${ }^{235}$ \\
- Sampling locations and dates were insufficient ${ }^{236}$
\end{tabular}

Table 2 is a re-classification of fourteen of the idealized arguments in Table 1 according to three typical areas of stakeholder concern, namely (1) calibration and shortage of data, (2) selection of flow rate, and (3) preference for site-specific data.

\section{Claims Involving Calibration and Shortage of Data}

Parties frequently claim that a model using only a few data points is invalid, and it is reasonable in most contexts to want more data and less uncertainty. However, we have identified as idealized the claim that a TMDL is flawed solely on the basis that taking more samples will always be superior to taking fewer samples. Even if the data is severely limited, the possibility exists that new data would not effect a reduction of the loading restriction. And, even if additional data reduced the loading restriction, the effect might be minimal. Therefore, we also identified challenges as idealized if stakeholders did not consider or speculate upon the effect of new data and its magnitude.

\section{Claims Involving an Agency's Flow Rate Selection}

For low flow TMDLs, agencies identified critical low flow rates and permitted discharges, and modeled the systems using these values. Critics responded by asserting that observed flows should be used because they are more realistic. We categorized these claims as idealized arguments based upon the premise that the effect or magnitude of the

233. See supra note 192 and accompanying text.

234. See supra note 193 and accompanying text.

235. See supra note 194 and accompanying text.

236. See supra note 196 and accompanying text. 
agency's substitution of permitted flow for observed flow was not evaluated.

\section{Claims of Failure to Use Site-Specific Data}

Parties frequently claim that inaccuracy in regulation arise from the use of default or textbook parameter values for model input, or the use of regression equations based on regional or national data. The use of reference watersheds, as well as data from lakes when regulating streams, are likewise targets of criticism. While these concerns are valid, we categorized as idealized those arguments that seemed to demand comprehensive site-specific data, as well as those that did not consider or speculate upon the effect of site-specific data and its potential magnitude.

Table 2: Classification of Idealized Arguments

Claims Involving Calibration of Model and Shortage of Data

\section{Argument}

- Model calibration poor, suggesting a high level of uncertainty $^{237}$

- Calibration based on only one water quality monitoring station $^{238}$

- Failure to account for tributaries to creek ("The calibration data are too sparse to make a valid calibration ...." $)^{239}$

- Failure to use local, site-specific data (one grab sample not adequate) ${ }^{240}$

- Failure to consider nonpoint source pollution, local conditions, and effect of sunlight ${ }^{241}$

- Failure to consider all sources of PCB contamination ${ }^{242}$
Type of Idealized Argument (from Table 1)

1.A., 3

1.B.

2.A.

237. See supra notes 115,192 and accompanying text.

238. See supra note 152 and accompanying text.

239. See supra note 178 and accompanying text.

240. See supra note 171 and accompanying text.

241. See supra note 170 and accompanying text.

242. See supra note 186 and accompanying text. 
Table 2 (continued)

Claims Involving Agency's Selection of Flow Rate

\section{Argument}

- Only four of seven discharging reservoirs taken into account $^{243}$

- Unrealistic flow scenarios were assumed (EPA model based on low-flow conditions) $)^{244}$

- EPA does not show water quality standards will be met under all conditions (and not simply critical low flow discharge $)^{245}$

\section{Claims Involving Failure to Use Site-Specific Data}

\section{Argument}

- Failure to use local, site-specific data ${ }^{246}$

- Uncertainty in regression equation is too great because data from sites outside region is inadequate ${ }^{247}$

- Insufficient data collection techniques and use of reference watershed inadequate ${ }^{248}$

- TMDL is deficient without site-specific stream data from each sub-basin ${ }^{249}$

- Further research needed (because of use of lake, not stream, data) ${ }^{250}$
2.A.

Type of Idealized Argument (from Table 1)

2.B.

1.C.
Type of Idealized Argument (from Table 1)

2.A.

1.A.

2.A.

2.A.

2.A.

243. See supra note 188 and accompanying text.

244. See supra note 174 and accompanying text.

245. See supra note 158 and accompanying text.

246. See supra note 171 and accompanying text.

247. See supra note 136 and accompanying text.

248. See supra note 181 and accompanying text.

249. See supra note 183 and accompanying text.

250. See supra note 173 and accompanying text. 


\section{RESULTS OF THE STUDY}

For regulatory science it has become a problem that there is no agreed upon end to research.... [S]cientific doubts become resources mobilized by different actors who have vested interest in public policy outcomes. The raising of doubts becomes a tactic of postponement, leading to the decision to commission another study. ${ }^{251}$

\section{A. Initial Qualification Regarding the Database of Idealized Arguments}

The foregoing selection of idealized arguments is only intended to confirm the presence of such strategies in TMDL disputes, and should not suggest that the majority of the scientific and technical arguments we studied are idealized. Depending on the number of dischargers affected by a TMDL, the number of scientific and technical challenges (and not legal, administrative, or other challenges ${ }^{252}$ ) found in comments to the draft TMDL, reports commissioned by dischargers, and notices of appeal, easily runs into the hundreds. We would roughly estimate the number of idealized arguments as constituting only ten to fifteen percent of the total number of technical and scientific challenges in the materials reviewed, such that the vast majority of arguments are not idealized. ${ }^{253}$

Examples of arguments we did not consider to be idealized include some challenges in the Skippack Creek TMDL controversy to Dr. Carrick's report that the EPA relied upon. In his commissioned response to Dr. Carrick, an expert noted that using chlorophyll $a$ concentration as a surrogate for periphyton biomass (as did Carrick) is confounded by species-specific differences and environmental conditions such as temperature and light, rendering insufficient a single sampling event; an alternative standard analytic method (not used by Carrick) is then proposed-including measurement of "algal biomass by having the algae

251. Margarita Alario \& Michael Brün, Uncertainty and Controversy in the Science and Ethics of Environmental Policy Making, THEORY \& SCI. (Vol. 2 2001), available at http://theoryandscience.icaap.org/content/vol002.001/02alariobrun.html (citing the findings in $\mathrm{M}$. RUSHEFSKY, MAKING CANCER POLICY (1986)).

252. Examples of such challenges would include procedural challenges (e.g., whether the TMDL is an "action" of PaDEP, or whether the parties had adequate time to respond to the TMDL); claims that the TMDL is arbitrary and capricious, or not supported by substantial evidence; claims that impairment listing decisions were improper; and complaints that compliance with the TMDL would be too expensive.

253. In the early phases of our study, we attempted to count the number of idealized arguments. About half of the scientific arguments seemed to contain at least one idealized "element" in our framework, with failure to identify effect and magnitude as dominant. However, most of the comments submitted did not fit into our framework because they were administrative, legal, or procedural; were requests for more data or clarification; or were simply too vague for analysis. 
enumerated and ... calculating the number and volume of algae" - and previous studies are used to demonstrate that Carrick's method "could give results [two] to [sixty] times greater than the standard method."254 Likewise, when the same expert raised questions about the pollution impact of nonpoint sources, he offered evidence of phosphorus loadings from agriculture, new development construction activities, roadway runoff, and streambank erosion, to demonstrate that more than half of the phosphorus load is from nonpoint sources. ${ }^{255}$ These arguments are not mere claims of insufficiency or scientific error, but alternative analyses alongside careful consideration of effect and magnitude.

In the Wissahickon Creek TMDL controversy, one comment pointed out that the Wissahickon watershed is four times larger than the Ironworks Creek reference watershed, and that because the steeper slope in the reference watershed lessens the likelihood of streambank erosion, the EPA underpredicted the sediment load in Wissahickon Creek. ${ }^{256}$ In its response, the EPA acknowledged the problem and revised its estimate of streambank erosion. ${ }^{257}$ Another non-idealized argument, in the Borough of Lansdale's comments on the Neshaminy Creek draft TMDL, pointed out that the intended seventeen percent reduction in point source phosphorus loading did not take into account the eleven percent reduction predicted from BMPs implemented in the stormwater program. In this instance, the EPA responded with a counterargument: stormwater phosphorus loads are delivered in wet weather events, while the "critical period for nuisance algal growth is during low flow conditions" (i.e., when there is no stormwater loading). ${ }^{258}$ Nevertheless, the Borough's challenge was specific as to the alleged defect and impliedly identified a significant effect resulting from an alternative analysis.

We also identified numerous non-idealized arguments in the notices of appeal filed with the Pennsylvania Environmental Hearing Board. For example, the various dischargers that appealed the Neshaminy Creek TMDL identified inconsistencies between the first and second drafts of the TMDL (the first draft stated that point source dischargers of nutrients were adequately addressed and further reduction was unnecessary; the second draft imposed a nearly sixty percent reduction for phosphorus), questioned the method of subtracting water impediment releases and

254. F.X. BROWNE, INC., supra note 103, at 3-4. Browne offers a chart showing water chemistry variations in Mill Brook to illustrate the deficiencies of limited sampling, and gives examples of other algae studies with vastly more samples than Carrick used. Id. at 4-5.

255. Id. at 17

256. WISSAHICKON RESPONSIVENESS SUMMARY, supra note 146, at 28, cmt. 35-24.

257. Id., response 35-24.

258. NESHAMINY CREEK COMMENTS/RESPONSES, supra note 152, at 9-10. 
estimated groundwater/septic sources from recorded stream flow to determine point source discharge (because that "significantly overestimates the contribution of municipal point source discharges"), and used PaDEP's own data to contradict the theory that nuisance algae growth is reducing dissolved oxygen in the creek. ${ }^{259}$

Finally, most of the comments in opposition to the Delaware PCB TMDL were not idealized, including identification of the risk of false positives (due to background noise contributed by sampling and laboratory artifacts) in the EPA's not yet EPA-approved draft test method to measure PCB concentration, and a challenge to the exclusion of nonpoint sources which demonstrated that "even if the point sources were allowed no discharge of PCBs at all, the resulting reductions would not lead to attainment of the standards in the [Delaware] River."260 Such criticisms go beyond identification of errors (and implied uncertainty) to consider the effect of alternative analyses.

\section{B. The Presence and Effectiveness of Idealized Arguments}

On the basis of the categories we developed to identify arguments that reflect an idealized conception of science, we were able to confirm the somewhat frequent, but not voluminous, use of strategies that focus on uncertainty or insignificant errors as a basis to weaken or delay regulation. Recalling the original categories that motivated this study, all of them seem to reflect demands for more certainty than can reasonably be expected in regulatory process: (1) manufacturing uncertainty by pointing out flaws and demanding more information prior to regulation; (2) deconstruction of regulatory analysis by highlighting areas of uncertainty; and (3) demanding sound science by requiring high levels of confidence before acting on a perceived problem. ${ }^{261}$ While we did not find very many examples of explicit idealizations - such as demands for complete certainty or objectivity (e.g., demanding disinterested research) — we did detect implicit idealizations where a demand for more certainty or additional data, in itself not an unreasonable demand, was not accompanied by an alternative analysis or consideration of the effect (and magnitude of the effect) of the alleged shortcoming.

\footnotetext{
259. Notice of Appeal, Hatfield Twp. Mun. Auth., supra note 166, 1 ๆ 25, 29, 53(a), (d).

260. Letter from Robert M. Matty, Jr., Manager of Envtl. Affairs, Exelon Power, to Lenka Berlin, EPA Region III (Oct. 21, 2003), at 5. Furthermore, it was noted that the method is extremely sensitive, and while data validation is necessary, the TMDL does not address false positives. Id. at $5-6$.

261. See supra Part I.
} 
In the process of identifying idealized arguments, we also came to the conclusion that idealized arguments were rarely, if ever, effective in weakening or delaying a regulatory burden. Two of the TMDLs we studied were withdrawn in part on the basis of an error in the scientific literature relied upon in establishing the TMDL—an error conceded by the authors of the study. Otherwise, the EPA and PaDEP are confident enough in their models, assumptions, data, and results, even as they concede some errors and uncertainties, to respond negatively to (or to ignore) arguments that lack specificity, genuine alternative analyses, or demonstrations that such alternative analyses would have a substantial effect on the proposed regulation. ${ }^{262}$ Reasonable scientific arguments made at the Comment stage sometimes resulted in minor changes to the TMDL, but conclusory accusations of too few data, too much uncertainty, or general modeling or sampling shortcomings were met with curt responses. In response to a comment that the draft of the Wissahickon Creek TMDL "is seriously flawed," does not "reflect current science," and is not "scientifically defensible," the EPA's statement that "the TMDL is based on scientifically valid data and procedures" and therefore "stands as is and will not be withdrawn or delayed" seems to exemplify the spirit of almost every response to such generalized arguments that we read. ${ }^{263}$ Most of the time the EPA and PaDEP are so aware of the limitations of their scientific analysis, as well as the ease with which dischargers identify minor errors and discrepancies, that these agencies are not moved by idealistic demands. Therefore, the ability of a stakeholder to delay or weaken regulation by idealized arguments is minimal. ${ }^{264}$

Moreover, arguments that demand more data or more accurate analyses without considering the effect of more data or offering an alternative analysis can sometimes backfire. When the Skippack Creek and Neshaminy Creek TMDLs were withdrawn, it was obvious that the revised TMDLs (to be issued in the near future) would be more stringent on dischargers. ${ }^{265}$ In our discussions with representatives and consultants for these dischargers, it was also obvious they were aware of this possible result. This confirms the possibility that arguments that "successfully" (from a strategic prospective) cause a delay may actually

262. See supra notes $116,119,121,125,127,153-55$ and accompanying text.

263. WISSAHICKON RESPONSIVENESS SUMMARY, supra note 146, at 19, cmt. 35-01, response 35-01.

264. But see supra note 181.

265. See Status Report, Lower Salford Twp. Auth., supra note 102 (noting the "TMDL as written is likely not stringent enough to attain applicable water quality standards"). 
result in stronger, more restrictive regulations. However, there is also the possibility, acknowledged by a consultant, that the next TMDLs for Skippack Creek and Neshaminy Creek will also not be based on sufficient data and sound analytic models, such that the new TMDLs will also be withdrawn.

Of course, appealing a TMDL issuance to the Environmental Hearing Board does cause a delay. Although we identified idealized arguments in notices of appeal, any controversy over their validity would occur in the scheduled hearing, and, in any event, most of the arguments made in the notices of appeal in our study were not idealized. However, the initial process of TMDL issuance - an informational meeting between regulators and stakeholders to review technical data, a draft TMDL sent out for public comment, a public meeting, publication of comments and responses, a final TMDL, and perhaps an appealhighlights the potential reasons why idealized arguments might be made. In our informal discussions with several attorneys who represent TMDL stakeholders, several local federal and state regulatory personnel, two consulting engineers, a developer who filed an appeal, and four university professors who specialize in regulatory science, we shared the results of our study and asked why idealized arguments are employed. Three distinct but related and completely unsurprising answers emerged:

(1) Given the complexity of the TMDL allocation, a stakeholder (working with counsel and consulting engineers) cannot realistically review, analyze, and propose modifications in a thirty-day comment period. There is time for brief written comments and responses, but not for substantial negotiations with the agency. Indeed, negotiations seem to take place after an appeal has been filed. Therefore, many challenges are raised as placeholders, that is, as issues to which one can return at a later date. If they are in retrospect exaggerated, unrealistic, or unreasonable, they can be bolstered or discarded.

(2) Closely related to the above, the period during which an appeal can be filed before the Pennsylvania Environmental Hearing Board is also limited to thirty days after notice of the TMDL, which means parties make numerous arguments to preserve the right to raise them in the hearing or in later appeals to a federal court (if the EPA established the TMDL). ${ }^{266}$ Prior to the hearing, the science supporting the TMDL can be investigated further and arguments can be developed. Moreover, under

266. See Notice of Appeal, City of Philadelphia, supra note 111, 21 (appealing its NPDES permit in part because it was based on the Wissahickon TMDL: "the Appellant has filed this appeal, in part, to preserve its right to challenge the validity of the TMDL for the Wissahickon Creek in the future in federal court"). 
the pressure of preparing for the hearing, and perhaps trying to avoid it, genuine negotiations can take place. In our subject TMDL controversies, it was quite common for the parties to agree mutually on stay requests and to present regular status reports to the administrative law judge. Again, the role of idealized arguments may be to serve as placeholders.

(3) Finally, irrespective of the intention to study the TMDL more closely or file an appeal, there is sometimes a conviction that a rigorous, scientific challenge to the TMDL can be developed with additional time, including running different models, performing formal uncertainty analyses, collecting more data, and offering an alternative analysis. An argument that might appear idealized is in fact an abstract for a more compelling, justifiable challenge to be developed. Thus, for example, the Conestoga TMDL changed appreciably after appeals were filed. One developer said his "team" was able to present solid evidence to convince PaDEP of several errors and shortcomings of its procedures; even though no changes to the TMDL were made during the comment phase, the TMDL was revised in response to the appeal. The Neshaminy, Skippack, and Anacostia TMDLs were also changed considerably (from the "final" published form) during the appeals (and before the Neshaminy and Skippack nutrient, but not sediment, portions of the TMDL were withdrawn). By contrast, the Wissahickon TMDL has not been changed, despite appeals. ${ }^{267}$ In all cases, the comment phase did not play any significant role in garnering revisions to the TMDL. Argumentative comments may serve as placeholders while the TMDL is analyzed, to preserve issues on appeal, to create an agenda for negotiations, or to lay the groundwork for a future robust scientific critique; idealized arguments, however, seem to have little effect on agency scientists, and little success except as place markers.

\section{The Problem(s) with TMDLs}

While we did not intend this study to provide specific insights for the ongoing policy disputes about the effectiveness of the TMDL program, the tensions between stakeholders who want better science-a view reflected in and supported by the NRC report-and those who acknowledge both the limitations of science and the need for immediate pollution abatement, ${ }^{268}$ were especially evident in our subject TMDL

\footnotetext{
267. There were apparently no discussions between PaDEP and the City of Philadelphia about technical objections to the TMDL, as the City was pursuing those issues with the EPA, which established the TMDL. See supra note 111.

268. See supra notes $31-41$ and accompanying text.
} 
controversies. From the latter perspective, the rush to create TMDLs is justified, but stakeholders have concerns that go beyond the problem of thirty-day comment periods and the thirty-day appeal period in Pennsylvania. Most TMDLs use subjective margins of safety and lack the data necessary for formal uncertainty analyses. That is why the stakeholders in our TMDL controversies identified missing variables or data shortage as fundamental flaws, and that is also why agencies responded that their selection of variables and their use of data is "appropriate." Everyone in the process knows the TMDL program would benefit from careful, quantitative uncertainty analyses, and that there would be less controversy (or at least a different, more scientific, controversy). The agencies have a deadline, however, even as stakeholders find little reason to accept errors and uncertainties simply because of temporal constraints. Those errors and uncertainties, from the stakeholders' perspective, have adverse and expensive consequences.

Another problem this study brings into relief is the artificial precision that is ubiquitous in the TMDL program. A "total daily load" implies a level of precision that neither the models nor the field conditions can produce. Insignificant omissions and errors can therefore easily be identified as "fundamental flaws"; agencies can never really justify with precision the figures the Clean Water Act requires they produce.

Finally, run-off based TMDLs have been shown to be planning documents poorly linked to implementation. This is the "fundamental disconnect" of the program; in concept, the federal government forces state governments to force municipal governments to force landowners to manage their land in a manner beneficial to the watershed. But this is not happening due to financial concerns, legal controversies, scientific or technical shortcomings, and, primarily, political barriers. Many of the benefits of implementing run-off based TMDLs would accrue in the future as habitat is restored and as downstream clean water flows in the watershed, the benefits of which are spread diffusely for the population. Costs, however, are immediate, local, and imposed on offending landowners. Moreover, elimination or reduction of the offending behavior is difficult due to lifestyles and population growth. This presents a losing formula for political action and explains much of the implementation inactivity. ${ }^{269}$

269. See, e.g., Mancur Olson, The Logic of Collective Action: Public Goods And the THEORY OF GrouPS (8th prtg. 1971). See generally David Zaring, Agriculture, Nonpoint Source Pollution, and Regulatory Control: The Clean Water Act's Bleak Present and Future, 20 HARV. ENVTL. L. REV. 515 (1996) (explaining "why potentially effective alternative solutions-such as 


\section{Non-scientific Solutions}

[M]ore attention should be given to the political process. Disputes should be understood and handled primarily as between people, only secondarily as between scientific theories...; and more attention should be given to negotiation and deliberation and less to proof. ${ }^{270}$

In contemporary law and science discourse, "politics" is often contrasted with scientific expertise, with the former construed as potentially distorting, interfering with, or eclipsing the latter in the regulatory process. ${ }^{271}$ For example, in the context of regulation to reduce the effects of global warming, "there were suggestions of widespread tampering by the Bush Administration with the global warming data reported by numerous federal agencies," including replacing (in an annual EPA report) language from a National Academy of Sciences Report (representing scientific consensus in climate change) with language from a study funded by the American Petroleum Institute that questioned climate change science. ${ }^{272}$ That discourse sometimes tends to idealize science's capacity to avoid politics and interests as if "interest groups" are always associated with industry and not with so-called environmentalists. Our point is that "politics" usually has pejorative connotations.

Politics, however, can be seen as a solution to regulatory controversies when the science runs out, ${ }^{273}$ when "the supply of ... scientific and technical information is far less than is needed to produce effective or comprehensive regulations...."274 The TMDL program

pollution taxes on farmers, or command and control regulation- have not yet been implemented by Congress, and why a less effective solution may indeed pass").

270. Alario \& Brün, supra note 251.

271. See, e.g., Rescuing SCIENCE from Politics: Regulation AND the Distortion of SCIENTIFIC RESEARCH (Wendy Wagner \& Rena Steinzor eds., 2006) (fourteen essays concerning abuse of science by special interests).

272. Jody Freeman \& Adrian Vermeule, Massachusetts v. EPA: From Politics to Expertise 3-4 (Aug. 2007) (unpublished working paper), available at http://ssrn.com/abstract=1008906. The authors also discuss accusations of administration interference in regulation of agriculture and protection of endangered species. $I d$. at 5 .

273. See generally Alario \& Brün, supra note 251. Indeed, politics might even play a central role before "the science runs out":

We argue for acknowledgement of the political process, for formulating issues first as between people, and only later and with great caution as scientific or ethical. That will avoid serious misunderstandings, for the general expectation is that scientific or ethical issues be resolved by proof or demonstration with reference to invoked or discovered standards; but issues are really resolved, or not, by negotiation — politics. Id.

274. Wendy E. Wagner, Stormy Regulation: The Problems that Result when Stormwater (and Other) Regulatory Programs Neglect to Account for Limitations in Scientific and Technical 
was arguably mandated without an appreciation of "these severe information constraints, [and] by insisting that regulatory requirements be based on scientific models that are often badly data-deprived and laden with theoretical uncertainties, these programs encounter decades of contested science and resultant regulatory paralysis." 275 That sense of hopelessness leads some to suggest that water pollution abatement may best be handled at the local (municipal or county) level instead of through state and federal regulations. ${ }^{276}$ Even at the state level, however, we observed a preference for negotiated settlements to avoid litigation over scientific shortcomings.

In the TMDL controversies we studied, two (Skippack and Neshaminy) were withdrawn but will soon be replaced and likely appealed to the Pennsylvania Environmental Hearing Board. The appeals in the Wissahickon, Delaware River (PCB), and Conestoga TMDLs were withdrawn, with the latter undergoing significant revisions during negotiations. In the potential future litigation over the forthcoming Skippack and Neshaminy TMDLs, we do not foresee idealized arguments as having any significant effect, but there will be a sufficient number of non-idealized arguments to reinstate the policy controversy over TMDLs. Do we delay the TMDL program until there is better science, as defined in the NRC report recommendations, or do we go forward with the best available science? Both sides in that debate can accuse the other of having an "attitude" - an "agenda" - that interferes with their scientific evaluations. ${ }^{277}$

\section{CONCLUSION}

Just as everyone agrees environmental regulation should be based on "good science," but do not agree on what that means, so everyone would likely agree unreasonable arguments have no place in regulatory scientific discourse. But when is an argument unreasonable? While there is no easy answer, in this study we attempted to identify

Information, 9 CHAP. L. REV. 191, 193 (2006).

275. Id. at 198; see also Andreen, supra note 21, at $539 \mathrm{n} .13$ ("The problem ... is that the water quality standards approach has never worked .... There has been too little stream quality data to support it, and too little political will ....").

276. See Malone, supra note 17, at 11,141. See generally A. Dan Tarlock, The Potential Role of Local Governments in Watershed Management, 32 ENVTL. L. REP. 11,273, 11,273 (2002) ("Because watersheds do not respect political boundaries, effective watershed conservation will require cooperation and coordination among all levels of government, including local units. Watershed conservation is one of the increasingly significant environmental protection roles local governments are playing for a variety of reasons, ranging from choice to coercion.").

277. See supra note 35. 
characteristics of unreasonable arguments, in the context of five TMDL controversies, by reviewing all of the scientific challenges and comparing those that were helpful or constructive with those that were not. We concluded there was a form of argument, appearing frequently (but always alongside many more "reasonable" arguments), that was less than helpful: arguments that claimed threshold failures but did not offer thresholds; arguments that did not consider the effect of errors or uncertainties, or its magnitude; and arguments that offered criticism but no alternative.

If there is a recommendation from this study that would be useful to attorneys representing stakeholders in the early stages of the TMDL process, it would be to avoid idealized arguments. The potential to delay, weaken, or avoid regulation is minimal, as such arguments do not move agency scientists. However, we recognize their utility as placeholders when environmental agencies move more quickly in regulating than stakeholders can in their critical evaluations. Appeals cause delay, and most appeals include idealized arguments, even as those types of arguments rarely stand alone. Moreover, it is not at all clear that attorneys (and their stakeholder clients) should be blamed for such delays - the urgent need for water quality regulation, the rushed process of establishing TMDLs, and the need for careful evaluation all combine to create a situation where an expensive appeal is the only available option.

In the context of litigation, when a judge idealizes science, idealized arguments have a lot of potential success. People listen if you idealize, and you get rejected if you openly acknowledge the inevitable limitations of science. But environmental agency bureaucrats are pragmatists, well aware of the limitations of their models, data, and resources; they do not idealize TMDL science, and they do not respond well to idealizations. 